The definitive, peer-reviewed and edited version of this article is published and can be cited as

Duran-Fernandez, R. and G. Santos (2014), 'A GIS Model of the National Road Network in Mexico', Research in Transportation Economics, Vol. 46, pp. 36-54. DOI: 10.1016/j.retrec.2014.09.004

\title{
A GIS Model of the National Road Network in Mexico
}

Roberto Duran-Fernandez ${ }^{1 *}$ and Georgina Santos ${ }^{2}$

${ }^{1}$ Transport Studies Unit, University of Oxford, UK

Tel: +52(55) 52495060

E-mail address: r.duran.fernandez@gmail.com

*Corresponding author

${ }^{2}$ School of Planning and Geography, Cardiff University, UK, and Transport Studies Unit, University of Oxford, UK

Tel: +44 (0) 2920874462

E-mail address: SantosG@Cardiff.ac.uk

\section{ABSTRACT}

This paper describes a benchmark methodology for building a GIS model of the National Road Network in Mexico. A model of the road network is useful because it can help to calculate the shortest route between any two locations linked to the road system. The model estimates an average speed for every section on the network according to its hierarchy, regional location, toll status and administration. Optimal routes can be estimated in terms of a time-minimisation criterion. The paper presents a statistical test that shows that the model's results have a small bias of +6 percent in comparison to observed travel times from the Mexican Ministry of Transport. This bias can be fixed using a linear transformation of estimated travel time.

Key words: GIS model, Mexican National Road Network, Mexico, optimal route, time-minimisation

JEL codes: R40, R41, R49 


\section{MEXICAN SUB-SYSTEM}

This paper presents the methodology followed to build the North American GIS Road Network Model, a tool that can be used to estimate optimal routes between any two nodes within the network using travel times as an optimisation criterion. The model uses cartographic data from the Topographic Digital Dataset (TDD) and the Municipal GeoStatistical Framework, published by the National Institute of Statistics, Geography, and Informatics (INEGI 2000a, 2000b). This dataset includes comprehensive cartographic data of the National Road System. It classifies each road according to the number of lanes, whether it is a toll or a free road, whether the federal or a state government administrates it, and whether the road is paved or unpaved. The dataset also includes the most important ferry routes and complete information on the rail network.

The Secretary of Communications and Transport (SCT), through the Administration of Federal Roads and Bridges (CAPUFE), offers a service on its website that traces routes between the most important cities in the country. The system, called "Traza tu Ruta", provides the user with information on the shortest route between any two cities including a description of the route, its total length, and the estimated travel time. The data is used in the present study to estimate the average speed in each section of the road network.

\subsection{Hierarchical Classification of the National Road System}

According to the SCT, the national road system in Mexico comprises 14 Federal Corridors with a total length of $17,356 \mathrm{~km}$. The Federal Corridors connect the most important cities in the country across the 31 states and the Federal District. The corridors include $6,630 \mathrm{~km}$ of four-lane roads ( 38 per cent of the total length) and 4,976 km of toll highways ( 28 per cent of the total length). The Federal Corridors are managed by the Federal Government. This subnetwork of Federal Corridors has the highest hierarchy in the model. It is shown as 'trunklines' on Figures 1 to 8. 
A secondary network connects inner cities with the main corridors and several local roads between the main corridors and their feeders. This subnetwork has an extension of $69,768 \mathrm{~km}$ and includes both federal and state roads. The length of the network administered by state governments is $39,635 \mathrm{~km}$, representing 56 per cent of its total length. Almost 95 percent of the secondary network comprises two-lane roads; however, it also includes $1,760 \mathrm{~km}$ of onelane roads, which are mainly located in Yucatan State. The secondary network is almost exclusively toll-free; however, it also includes $969 \mathrm{~km}$ of toll roads. The road network is completed by $90,965 \mathrm{~km}$ of unpaved roads. It comprises $14,744 \mathrm{~km}$ and $39,140 \mathrm{~km}$ of two and one lane unpaved roads, respectively.

Finally, the network includes two main ferry routes connecting the Baja California Peninsula with the main continental landmass (La Paz-Mazatlan, and Santa Rosalia-Guaymas), and the Caribbean islands of Cozumel and Isla Mujeres with the Yucatan Peninsula.

\subsection{Construction of the Model}

The objective of the model is to work as a tool to calculate the optimal route between any two locations, which is defined as the route which minimises travel time. In order to do this, the model needs to assign an average speed to each section of the network.

The SCT publishes on its website estimated travel times for routes between selected cities in the country. For each route, average travel time is disaggregated by road section depending on whether the section is toll-free or tolled. The data also includes the state where each section is. This data is extrapolated to the rest of the sections of the road network following a special criterion for each road hierarchy, which is explained below.

\subsubsection{Federal Corridors}

The SCT presents estimated travel times for all the 14 Federal Corridors on the network. For any corridor, the speed that is allocated to the sections lying in a particular state is equal to the 
average speed of all the sections in that state. This exercise is performed separately for toll and toll-free roads. For sections that cannot be related to a specific state, the average speed assumed is that of the neighbouring sections within the same corridor.

According to SCT data, the average speed of the Federal Corridors is $107 \mathrm{~km} / \mathrm{h}$ on toll highways and $85.9 \mathrm{~km} / \mathrm{h}$ on toll-free roads. Average speed does no present significant variations across toll highways; however, the variances across toll-free sections are significant (Figures 9 and 10).

\subsubsection{Secondary Network}

The secondary network is divided in eight macroregions. ${ }^{1}$ For each macroregion, we select a sample of routes and estimate their travel time and average speed according to SCT data. Due to the fact that the SCT does not present information for all the sections of the secondary network, we extrapolate the data from the sample to the rest of the roads in the region, assigning to each of them the estimated average speed of the routes in the sample.

For each macroregion, we calculate the average speed and standard deviation of its roads. If in any macroregion the standard deviation is higher than an arbitrary threshold, we split it in smaller areas following the NUTS3 division for Mexico as presented in the paper. To each of these regions we assign the average speed of the sampled routes in their respective territories.

a. Sample The criterion for selecting the sample was to choose for each macroregion, routes that cover the maximum possible area. In particular, we selected feeders crossing through the longest axis of a region, which typically connects the interior cities of a region with the Federal Corridors, local roads, which connect the corridors that cross a region, secondary lines parallel to a Federal Corridor, and state circuits connecting dense populated areas. The sample for each region is described below.

\footnotetext{
${ }^{1}$ Macroregions are as defined by Bassols-Batalla (1993, 2002).
} 
i. Region I Northwest: The sample in this macroregion includes a federal and a state feeder, which connect east Sonora (S126) with the Federal Corridor II. In addition, it includes a north-south local road along the Sonora (S126) mountain range in its longest axis. The sample also includes two feeders between coastal Sinaloa (S125) cities and its mountain range, as well as a feeder in Baja California (S102). Due to the fact that almost all the cities in Baja California Peninsula are connected to the Federal Corridor XIII, no additional sample was taken.

ii. Region II North: The sample of routes includes a federal feeder that starts in the northern border and ends in central Chihuahua (S108), the Monclova-Torreon local road in Coahuila (S105), a feeder between sierra de Durango (S110) and its capital city, and two state feeders in Zacatecas (S132). In addition, it includes a free federal road between Durango (S110) and Chihuahua (S108). The Durango and Tarahumara Mountains are not connected, however the route Chihuahua-Sonora crosses this range and it is included as a separate observation in the sample.

iii. Region III Northeast: The sample includes a federal local road that links all the border cities in the region, a central local road that connects central Nuevo Leon (S119) with the Gulf of Mexico, and two feeders that link Ciudad Victoria, in Tamaulipas (S128) with the northern part of The Huastecas (R1131) and the central part of the state.

iv. Region IV Central-West: The sample includes the coastal line of Jalisco (S114) and the main feeder between Guadalajara and the south coast of the state. In addition, it includes four principal local roads: Uruapan- Guzman (between the west and east section of corridor VIII), Irapuato-Zamora (between Federal Corridors I and III), Silao-San Luis de la Paz (between Federal Corridors II and III), and Zitacuaro-Dolores (between Federal Corridors I and II). 
v. Region V Central: The sample of secondary routes in this region includes a semiarc composed of all the federal roads that surround the Federal District (S109). The northern arc runs from Atlacomulco to Sahagun, through Mexico (S115) and Hidalgo (S113) sate. The south-western arc continues from Atlacomulco to Izucar, through the states of Mexico (S115), Morelos (S117), and ends in Puebla (S121). The eastern part of the arc is extended between Ciudad Sahagun to Puebla, in the sates of Hidalgo (S113) and Puebla (S121). Finally, the southeast extreme of the arc is closed by corridor XI, a primary road, so it is not included in the sample. The sample also includes a local road between corridor V and XII in the south easternmost extreme of the region.

vi. Region VI South: The sample includes the federal line that runs along the Pacific coast between Manzanillo and Tapachula, and lies in the states of Sinaloa (S125), Jalisco (S114) Colima, (S106), Michoacan (S116), Guerrero (S112), Oaxaca (S120), and Chiapas (S107). In addition, it includes the route through the mountain range from Apatizingan, to Oaxaca (S120), via Chilpancingo and Ciudad Altamirano, through the states of Michoacan (S116), Guerrero (S113) and Oaxaca (S120). In addition, it includes three federal feeders that link the Pacific coast to inner Guerrero (S113), northwest Oaxaca (S120), and the northeast of the state. Finally, it includes two routes from Chiapas (S107), first an interior semiarc that links the inner cities in the state to the main network, and a feeder that connects the southern border to Federal Corridor V.

vii. Region VII East: The sample includes Tuxpan-Ciudad Valles, which is a local road that links corridors IV and VIII in The Huastecas microregion. In central Veracruz (S130), it includes a local road between corridors V, X, and XII (these are, Perote-Poza Rica, and Veracurz-Orizaba in Veracruz S130). In the Papaloapan Basin it includes two secondary federal lines that run along the section Puebla-Coaztacoalcos of Federal Corridor V (Puebla S121 and Veracruz S130). In the Tehuantepec Isthmus it does not include any additional road given that all the settlements are served by corridor IX. Finally, the sample includes the route 
Escarcega-Tenosique-Villahermosa, and the route Villahermosa-Paraiso-Chotalpa both in the state of Tabasco (S127).

viii. Region VIII Yucatan Peninsula: The sample includes two routes: first, Merida-Carrillo Puerto-Tizimin, which is part of the inner circuit of the peninsula, and second, Tikul-Dzilam Bravo, which is the longest route that links inner Yucatan (S131) to the northern coast of the peninsula.

b. Sub-Regional Variations The estimated regional average speeds exhibit important variations across regions, with the South being the one with the lowest speeds $(68.7 \mathrm{~km} / \mathrm{h})$ and the Yucatan Peninsula and the Northern macroregion being the ones with the highest speeds $(87.9$ and $86.08 \mathrm{~km} / \mathrm{h})$. The speed variations -measured as standard deviation $\sigma_{v^{-}}$ across sampled routes in each region are low in all regions except for the South $\left(\sigma_{\mathrm{v}}=104\right)$ and the East $\left(\sigma_{\mathrm{v}}=35\right)$. The variation in the Northwest macroregion is also relatively high $\left(\sigma_{v}=31.4\right)$. However, when the route that crosses the mountain range of Sonora is excluded speed variation takes a considerable lower value $\left(\sigma_{\mathrm{v}}=20.1\right)$, as shown on Figure 11 .

The estimated average speed for each macroregion is extrapolated to all the roads located within their limits. However, given the sub-regional variations mentioned above, we follow a special criterion for the Northwest, the South, and the East (macroregions I, VI, and VII). This criterion is described below.

i. Region I Northwest: The route that connects central Sonora (S126) to the mountain range (Hermosillo-Sarihuapa) is excluded from the sample and the estimated average speed is allocated to all the roads in macroregions I, VI, and VII, except for those located on the Sonora Mountain (R1100). A special region is formed by roads in the Sonora and Chihuahua 
Mountain. The average speed allocated to this special region is equal to the speed of the route connecting its extremes through its largest axis (Sarihuapan-Chuahtemoc).

ii. Region VI South: The region is subdivided in five areas. The first is the Pacific Coast, starting in the east in Manzanillo and ending in Salina Cruz in Sinaloa (S125), Oaxaca. This special region extends to the north, up to the southern part of the Sierra Madre Occidental. The average speed allocated to this area is equal to the speed of the Manzanillo-Salina Cruz route described above. Three areas are defined over the mountain zone of Guerrero (S112) and Oaxaca (S120): Guerrero Mountain, West Oaxaca Mountain, and East Oaxaca Mountain. The average speed allocated to each of these areas is the same speed allocated to the routes that link the Pacific coast to the central plateau of Mexico. These include Iguala-Zihuatanejo, Izucar de Matamoros-Puerto Escondido, and Tuxtepec-Puerto Escondido. The average speed assigned to the northern area of Michoacan (S116), Guerrero (S112), and Oaxaca (S120) corresponds to the speed of the Apatzingan-Oaxaca route. It crosses the region from west to east through the northern extreme of the Sierra Madre Mountains. Finally, the average speed assigned to roads in Chiapas (S107) is equal to the average speed of the routes connecting the centre of the state and its southern border.

iii. Region VII East: The region is divided in three areas. The first is central Veracruz, which covers the area between the Huastecas and Xalapa, the second is the Veracruz Mountains, which covers the area between Xalapa and Orizaba, and the third is the Papaloapan Basin and Tabasco (S127). Except for the last area, the rest of the special regions lie completely within Veracruz (S130). Two additional areas are considered. The first is the microregion of the Huastecas, which extends itslf through the borders of Tamaulipas (S128), Hidalgo (S113), San Luis Potosi (S124), and Veracruz (S130). The average speed for the roads in this region is equal to the average speed on the route Tuxpan-Cd. Valles, via Molango. The Tehuantepec Isthmus is the other special region, and the average speed allocated to its roads is equal to the average speed of the Federal Corridor IX. 


\subsubsection{Unpaved Network}

The SCT does not provide any data on estimated travel time of unpaved roads in the country. Only few small and remote settlements are connected to the main road network exclusively through unpaved roads. Nevertheless, it is important to allocate an average speed to the unpaved network in order to complete the model. Therefore, each unpaved road is allocated a base speed as if it were a secondary road. The average speed allocated is equal to a fraction of this base speed. In our model this fraction is 20 percent.

\subsubsection{Urban Areas}

When a corridor or secondary road crosses a metropolitan area, the average speed decreases due to the congestion on urban roads. The SCT publishes the average speed on urban roads for selected cities. We select a sample of seven cities where this data is available and we calculate an average speed of $51.6 \mathrm{~km} / \mathrm{h}$. Variations in urban speeds across cities is very small $\left(\sigma_{\mathrm{v}}=16.12\right)$.

We select eleven metropolitan areas with population higher than 800,000 . These cities are Mexico City (R1126), Guadalajara (R1047), Monterrey (R1074), Puebla (1081), Ciudad Juarez (R1029), Tijuana (R1005), Leon (R1128), Toluca (R1055), Torreon (R1125), San Luis Potosí (R1091), and Merida (R1134). We allocate an average speed of $51.66 \mathrm{~km} / \mathrm{h}$ to all paved roads that lie in the urban area of these eleven cities. Toll highways and unpaved roads keep their original speeds. ${ }^{2}$

\subsubsection{Ferry Lines}

The average travel time of each ferry line was taken directly from the local service provider's internet website.

\footnotetext{
${ }^{2}$ The territory for each metropolitan area follows the classification presented in the appendix.
} 


\subsection{Accuracy Test}

According to the model, the estimated average speed on Federal Corridors is $89.3 \mathrm{~km} / \mathrm{h}$ while on secondary roads it is $75.19 \mathrm{~km} / \mathrm{h}$. The inter-state variations of this variable are considerable for both types of roads, with a standard variation of 59.0 and 42.1 for corridors and secondary roads, respectively. The state with the lowest average speed (apart from the predominantly urban state of Mexico S115 and the Federal District S109) is Oaxaca (S120), followed by Puebla (S121), Guerrero (S112), and Veracruz (S130). It is worth mentioning that road density is not necessarily low in these states, showing that this variable might not be the ideal proxy for measuring the effects of road infrastructure in a particular geographic area (Table $1)$.

We test the accuracy of the model by estimating the average travel time of a random sample of routes and comparing it to the travel time published by the SCT. The sample is drawn from a population of 135 cities, ${ }^{3} 20$ maritime ports, 21 northern-border crossing points, and four southern-border crossing points. The number of possible routes that can be traced between any of these nodes is 32,400 , clearly illustrating the need of using sampling methods for testing the model. The selected sample includes 30 random routes, as described in Table 2.

We estimate the travel time for each route in the sample using two methods. The first is the unrestricted optimal path, whose algorithm calculates the minimum cost between the two nodes, taking as impedance variable the travel time of each section on the network. The algorithm selects sections independently of their hierarchy. The second method uses a hierarchical algorithm. ${ }^{4}$ This method estimates the path with the smallest cost between any two nodes, selecting the road with the highest hierarchy when two or more options are available, independently of the cost. When only roads of the same hierarchy are available, it selects the road with the lowest impedance, in this case, with the highest speed. The algorithm is heuristic and it does not calculate optimal routes. A characteristic of the hierarchical

\footnotetext{
${ }^{3}$ These are the main settlements of each region of the NUTS3 classification of the appendix.

${ }^{4}$ To do this we use the Network Analyst utility of ArcMap 9.1.
} 
algorithm is that it does not necessarily trace a direct route for every two nodes on the network, so the complete set of routes has to be found using an application of the minimum path problem, in this case, the Dijkstras algorithm. Despite its restrictions, the hierarchical algorithm may trace more realistic routes than an unrestricted algorithm.

The estimated travel times under the two methods are compared with the data from the SCT. The comparison shows that the unrestricted model overestimates travel times by +6 percent while the hierarchical model presents a bias of +10 percent. In absolute terms, the error of the unrestricted model is +37 min for the typical route, while the error for the hierarchical model is +1 h 9 min. For the unrestricted model the estimated bias lies between +6 and +8 percent with a confidence interval of 95 percent. This error is estimated using a sample that is representative at national level, a linear transformation of the estimated time for any route can be applied to generate completely unbiased results (Table 3). The transformed travel times are the basis for the final version of the model.

The test shows that the unrestricted model is more accurate than the hierarchical model. This suggests that in this context the introduction of the hierarchical algorithm is not necessary for the estimation of more realistic routes. Finally, the test shows that the model emulates the data published by the SCT with great accuracy.

\section{USA SUBSYSTEM}

In this section, we present an extension to the model, which merges Mexico's GIS road network model, with a model of the USA road infrastructure, published by the Bureau of Transportation Statistics (BTS 2006) of this country. The result of this application is a complete North American GIS Road Network Model. It is based on digital cartographic information on the road network in the 48 contiguous USA sates, and Mexico. 


\subsection{Data for the USA Road Infrastructure}

The cartographic data of the USA road network was taken from the National Transportation Atlas Database of the Bureau of Transportation Statistics (BTS 2006). The model uses all the roads in this dataset including federal, state, and local roads. The dataset does not include local roads in urban areas. Cartographic data is complete and no further modifications on the dataset were necessary.

Following Schürman and Tallat (2000), the average speed was estimated according to posted speed limits at state level. First, all roads were classified in hierarchies according to their type and number of lanes. The hierarchical classification follows the Tyger/Census Bureu Classification presented in Table 4.

Each set of roads in each hierarchy was classified in urban or rural according to the information presented in BTS (2006). Maximum posted speed limits were taken from the Insurance Institute for Highway Safety (IIIHS 2007). The Interstate Highway System (IHS) is included in the first hierarchy. Roads in the second hierarchy are defined as other limited access roads. Finally, roads in hierarchies three and four are classified as other roads. Urban and rural roads were allocated different average speeds. The dataset considers that a road is urban when it lies in an urban area with a population of 50,000 or more.

\subsection{USA-Mexico Interconnections}

Mexico and the USA are connected through 25 international border ports distributed across their common border. Twenty-one of them are fully commercial ports. The geographical location for each border port was obtained from the National Transportation Atlas Database, (BTS 2006) and validated with information from the USA Department of Transportation, published on Google Earth. The classification into commercial and non-commercial border ports follows schedules for each port published by SCT (Figure 12). 
The USA and Mexico networks are not physically connected in the GIS model. An artificial line was added to the model for every border port. The length of each artificial connector was never more than nine $\mathrm{km}$. Locations with more than one border port were connected only through one artificial line. Table 5 lists the 26 international ports between the two countries.

The only available data on average crossing time is available from the Texas Transportation Institute (TTI 2002). It presents estimated crossing times for three of the main USA-Mexico border ports: El Paso (POE08), Laredo (POE12), and Tijuana (POE01). The crossing time used in the model is the $95^{\text {th }}$ percentile average crossing time, which is 45.2 minutes. It is worth mentioning that the Texas Transportation Institute study was carried out before the tragic events of $09 / 11$, therefore, the delays due to modifications in security inspection might be higher today (Table 6).

The estimated crossing time between border regions in the model is equal to the estimated $95^{\text {th }}$ percentile crossing delay of the Texas Transportation Institute report. However, for routes connecting non-border regions we consider an additional delay of four hours. This time considers the delay of the trailer transfer before and after crossing the border port.

\section{FINAL REMARKS}

We have presented a benchmark methodology for building a GIS model of the National Road Network in Mexico and linking it to the USA one by adding an artificial line for every border port. The model is useful for estimating the shortest route between any two points linked to the road system. The model estimates the average speed for every section on the network according to its hierarchy (national roads, secondary roads connecting inner cities with the main corridors or between the main corridors and their feeders, and two main ferry routes connecting the Baja California Peninsula with the main continental landmass and the 
Caribbean islands of Cozumel and Isla Mujeres with the Yucatan Peninsula), regional location, toll status (tolled road or free road) and administration (federal or state).

The model can identify optimal routes by minimising travel time, although with a small bias of +6 percent in comparison to observed travel times, taken from the Mexican Ministry of Transport. This bias can be easily fixed using a linear transformation of estimated travel time, making the model useful as a stand-alone tool.

\section{Acknowledgements and disclaimer}

The authors are grateful to two reviewers for helpful comments on an earlier version of this paper. This study was financed by the Mexican Federal Government through the National Council of Science and Technology (CONACYT). Any opinions, findings, conclusions and recommendations expressed in this paper are those of the authors alone and should not be attributed to any other person or entity.

\section{REFERENCES}

Bassols-Batalla, A. (1993) "Formación de regiones económicas" UNAM, Mexico City, Mexico.

Bassols-Batalla, A. (2002) "Geografía socioeconómica de México" Trillas, Mexico City, Mexico.

BEA (2004a) "Bureau of Economic Analysis' Economic Areas" Internet publication from the Bureau of Economic Analysis http://www.bea.gov/regional/docs/econlist.cfm

BEA (2004b) "Bureau of Economic Analysis' Regions" Internet publication from the Bureau of Economic Analysis http://www.bea.gov/regional/docs/regions.cfm 
BTS (2006) "National Transportation Atlas Database" Internet publication from the Bureau of Transportation Statistics http://www.bts.gov/publications/north_american_transportation_atlas_data/

IIHS (2007) "Maximum posted speed limits for passenger vehicles." Internet publication from the Insurance Institute for Highway Safety http://www.iihs.org/laws/state_laws/speed_limit_laws.html

INEGI (2000a) "Conjunto de datos vectoriales y toponímicos: Carta digital" CD-Rom from the Instituto Nacional de Estadística, Geografía e Informática, Aguascalientes, Mexico.

INEGI (2000b) "Marco geo-estadístico municipal" CD-Rom from the Instituto Nacional de Estadística, Geografia e Informática, Aguascalientes, Mexico.

Schürman, C. and Tallat, A. (2000) "Towards an European peripherally index" Report for the European Commission, prepared by Institut für Raumplanung, Universität Dortmund, Dortmund, Germany.

TTI (2002) "International Border Crossing Truck Travel Time for 2001" Report for the Federal Highway Administration and the Department of Transportation, prepared by the Texas Transportation Institute, Texas A\&M University System, TX, USA. 
Table 1 Average Speed by State National Road System Model

\begin{tabular}{|c|c|c|c|c|c|}
\hline & & \multicolumn{2}{|c|}{ Federal Corridor } & \multicolumn{2}{|c|}{ Secondary Roads } \\
\hline & & $\begin{array}{l}\text { Length } \\
\mathrm{km}\end{array}$ & $\begin{array}{c}\text { Average } \\
\text { Speed } \\
\mathrm{km} / \mathrm{h} \\
\end{array}$ & $\begin{array}{l}\text { Length } \\
\mathrm{km}\end{array}$ & $\begin{array}{l}\text { Average } \\
\text { Speed } \\
\mathrm{km} / \mathrm{h} \\
\end{array}$ \\
\hline \multicolumn{2}{|c|}{ National } & $17,356.69$ & 89.30 & $69,768.87$ & 75.19 \\
\hline S101 & Aguascalientes & 78.15 & 91.30 & 602.86 & 76.78 \\
\hline S102 & Baja California & 977.21 & 101.88 & $1,155.75$ & 74.16 \\
\hline S103 & Baja California Sur & 952.71 & 77.94 & 568.21 & 75.36 \\
\hline S104 & Campeche & 634.66 & 90.49 & $1,482.12$ & 88.89 \\
\hline S105 & Coahuila & 770.27 & 92.38 & $2,385.36$ & 83.70 \\
\hline S106 & Colima & 118.64 & 94.31 & 509.51 & 82.07 \\
\hline S107 & Chiapas & 607.12 & 91.58 & $2,707.64$ & 78.78 \\
\hline S108 & Chihuahua & 668.06 & 96.64 & $3,870.87$ & 78.56 \\
\hline S109 & Distrito Federal & 85.07 & 64.83 & 470.63 & 51.94 \\
\hline S110 & Durango & 672.25 & 81.97 & $2,155.86$ & 81.28 \\
\hline S111 & Guanajuato & 347.41 & 94.22 & $2,210.04$ & 75.12 \\
\hline $\mathrm{S} 112$ & Guerrero & 212.06 & 113.91 & $2,483.88$ & 71.61 \\
\hline S113 & Hidalgo & 155.56 & 95.94 & $1,928.97$ & 77.20 \\
\hline S114 & Jalisco & 733.76 & 93.10 & $4,129.28$ & 74.74 \\
\hline S115 & México & 555.47 & 77.59 & $4,105.37$ & 68.51 \\
\hline S116 & Michoacán & 765.05 & 90.20 & $3,357.49$ & 75.39 \\
\hline S117 & Morelos & 188.41 & 95.31 & 808.51 & 78.79 \\
\hline S118 & Nayarit & 252.28 & 94.66 & 967.78 & 76.78 \\
\hline S119 & Nuevo Leon & 833.94 & 85.13 & $3,078.50$ & 71.45 \\
\hline S120 & Oaxaca & 682.52 & 64.97 & $2,835.32$ & 63.87 \\
\hline S121 & Puebla & 509.16 & 90.67 & $2,746.15$ & 65.82 \\
\hline S122 & Querétaro & 113.87 & 112.99 & $1,042.79$ & 78.91 \\
\hline S123 & Quintana Roo & 596.76 & 93.56 & $1,162.27$ & 90.00 \\
\hline S124 & San Luis Potosi & 685.74 & 82.46 & $1,723.10$ & 72.85 \\
\hline S125 & Sinaloa & 751.26 & 94.01 & $1,792.75$ & 75.36 \\
\hline S126 & Sonora & $1,159.88$ & 102.69 & $4,098.18$ & 73.42 \\
\hline S127 & Tabasco & 279.22 & 92.93 & $2,229.34$ & 86.23 \\
\hline S128 & Tamaulipas & 858.89 & 87.19 & $2,572.87$ & 72.95 \\
\hline S129 & Tlaxcala & 123.38 & 88.28 & 741.18 & 78.94 \\
\hline S130 & Veracruz-Llave & $1,373.52$ & 93.61 & $4,006.44$ & 71.33 \\
\hline S131 & Yucatán & 332.91 & 83.02 & $3,387.72$ & 85.12 \\
\hline $\mathrm{S} 132$ & Zacatecas & 281.50 & 95.33 & $2,452.15$ & 82.83 \\
\hline
\end{tabular}

Source: Own estimates based on the Topographic Digital Dataset, INEGI (2000a) 
Table 2 Accuracy Test Sample

$(N=30)$

\begin{tabular}{lccccc}
\hline \hline \multirow{2}{*}{ Route } & \multicolumn{2}{c}{ Distribution } & & \multicolumn{2}{c}{ Sample } \\
\cline { 2 - 3 } \cline { 5 - 6 } & No. & $\%$ & & No. & $\%$ \\
\hline \hline City-City & 9,180 & 56.4 & & 19 & 63.3 \\
City-Port & 2,700 & 16.6 & & 2 & 6.7 \\
City-Border & 3,375 & 20.7 & & 8 & 26.7 \\
Port-Port & 210 & 1.3 & & 0 & 0.0 \\
Port-Border & 500 & 3.1 & & 0 & 0.0 \\
Border- & & & & \\
Border & 325 & 2.0 & & 1 & 3.3 \\
\hline Total & 16,290 & 100.0 & & 30 & 100.0 \\
\hline \hline
\end{tabular}

Table 3 Mean Differences between Models

\begin{tabular}{lrrrrrr}
\hline \hline & \multicolumn{2}{c}{ CAPUFE - U. Model } & & \multicolumn{2}{c}{ CAPUFE - H. Model } \\
\cline { 2 - 3 } \cline { 6 - 7 } & Absolute & As \% of & & Absolute & As \% of \\
& \multicolumn{1}{c}{$h$} & CAPUFE & & \multicolumn{1}{c}{ CAPUFE } \\
\hline \hline Mean & 0.63 & $6 \%$ & & 1.16 & $10 \%$ \\
Standard Deviation & 0.9 & 0.09 & & 1.2 & 0.11 \\
CV (Std.Dev/Mean) & 1.43 & 1.42 & & 1.04 & 1.03 \\
Sample Size & 30 & 30 & & 30 & 30 \\
\hline \hline Source: Own estimates as explain in text & & & &
\end{tabular}

Table 4 Allocation of Posted Speed Limit According to Road Type

\begin{tabular}{cll}
\hline \hline Hierarchy & Description & IIHS Posted Speed \\
\hline \hline 1 & Interstate Highway System & $\begin{array}{l}\text { Interstate Highway } \\
\text { System }\end{array}$ \\
& Limited Access Non-Interstate Highway & $<4$ Lane Non-Interstate \\
2 & System & $>4$ Lane USA Highway \\
3 & Non Limited Access USA Highways & $>4$ Lane Local \\
4 & Local Roads
\end{tabular}


Table 5 USA-Mexico Border Ports of Entry

\begin{tabular}{|c|c|c|c|c|c|}
\hline & \multicolumn{2}{|c|}{ Port of Entry } & \multicolumn{2}{|c|}{ State } & \multirow{2}{*}{ Ports } \\
\hline & Mexico & US & Mex & USA & \\
\hline \multicolumn{3}{|c|}{ Commercial } & & & Ports \\
\hline POE01 & Tijuana & San Isidro/Otay & $\mathrm{BC}$ & $\mathrm{CA}$ & 2 \\
\hline POE02 & Tecate & Tecate & $\mathrm{BC}$ & $\mathrm{CA}$ & 1 \\
\hline POE03 & Sonoita & Lukerville & SON & $\mathrm{AZ}$ & 1 \\
\hline POE04 & Agua Prieta & Douglas & SON & $\mathrm{AZ}$ & 1 \\
\hline POE05 & Naco & Naco & SON & $\mathrm{AZ}$ & 1 \\
\hline POE06 & Heroica Nogales & Nogales Deconcini & SON & $\mathrm{AZ}$ & 2 \\
\hline POE07 & Puerto Palomas & Columbus & CHI & NM & 1 \\
\hline POE08 & Juarez & El Paso & $\mathrm{CHI}$ & TX & 5 \\
\hline POE09 & Manuel Ojinaga & Presidio & CHI & $\mathrm{TX}$ & 1 \\
\hline POE10 & Ciudad Acuña & Del Rio/Amistad & $\mathrm{COA}$ & $\mathrm{TX}$ & 2 \\
\hline POE11 & Piedras Negras & Eagle Pass & $\mathrm{COA}$ & $\mathrm{TX}$ & 1 \\
\hline POE12 & Nuevo Laredo & Laredo & TAMP & TX & 5 \\
\hline POE13 & Heroica Matamoros & Brownsville & TAMP & TX & 4 \\
\hline POE14 & Reynosa & Hidalgo/Pharr & TAMP & TX & 2 \\
\hline POE15 & Nuevo Progreso & Progreso & TAMP & TX & 1 \\
\hline POE16 & Ciudad Camargo & Rio Grande Cit & TAMP & TX & 1 \\
\hline POE17 & Ciudad Miguel Aleman & Roma & TAMP & TX & 1 \\
\hline POE18 & Mexicali & Calexico/Calexico East & $\mathrm{BC}$ & $\mathrm{CA}$ & 2 \\
\hline POE19 & Los Algodones & San Andrade & $\mathrm{BC}$ & $\mathrm{CA}$ & 1 \\
\hline POE20 & San Luis Rio Colorado & San Luis Rio Colorado & SON & $\mathrm{AZ}$ & 1 \\
\hline POE21 & Sasabe & Sasabe & SON & $\mathrm{AZ}$ & 1 \\
\hline \multicolumn{6}{|c|}{ No Commercial } \\
\hline POE22 & Gustavo Diaz Ordaz & Los Ebanos (Ferry) & TAMP & $\mathrm{TX}$ & 1 \\
\hline POE23 & Guadalupe Bravo & Fabens & $\mathrm{CHI}$ & $\mathrm{TX}$ & 1 \\
\hline POE24 & Presa Falcon & Falcon Dam & TAMP & $\mathrm{TX}$ & 1 \\
\hline POE25 & El Berrendo & Antelope Wells & $\mathrm{CHI}$ & NM & 1 \\
\hline
\end{tabular}

Table 6 Estimated Delays in selected USA-Mexico Ports of Entry

\begin{tabular}{|c|c|c|c|c|}
\hline \multirow{2}{*}{$\begin{array}{l}\text { Port of } \\
\text { Entry }\end{array}$} & \multirow{2}{*}{ Туре } & Average Delay ${ }^{\prime 1}$ & $\begin{array}{c}\text { Average Crossing } \\
\text { Time }^{/ 2}\end{array}$ & $\begin{array}{c}95 \text { th } \\
\text { Percentile }^{/ 3} \\
\end{array}$ \\
\hline & & minutes & minutes & minutes \\
\hline \multirow[t]{2}{*}{ All } & Outbound & 24.9 & 17.2 & $45.2 *$ \\
\hline & Inbound & 11.6 & 33.8 & 64.9 \\
\hline \multirow[t]{2}{*}{ El Paso } & Outbound & 29.6 & 13.2 & 34 \\
\hline & Inbound & 4.2 & 37.2 & 77.4 \\
\hline \multirow[t]{2}{*}{ Laredo } & Outbound & 18.9 & 17.2 & 45 \\
\hline & Inbound & 15.4 & 31.2 & 54.9 \\
\hline \multirow[t]{2}{*}{ Otay } & Outbound & 28.6 & 19.1 & 36.9 \\
\hline & Inbound & 9.6 & 35 & 64.3 \\
\hline \multirow{2}{*}{\multicolumn{5}{|c|}{$\begin{array}{l}11 \text { Difference between the average crossing time and the free-flow } \\
{ }^{12} \text { Average time to travel between the starting point in the export } \\
\text { point in the importing country } \\
{ }^{12} \text { Crossing time for the } 95 \text { th percentile time for trucks to travel. } \\
\text { Source: International Border Crossing truck Travel Time } 2001\end{array}$}} \\
\hline & & & & \\
\hline \multicolumn{5}{|c|}{ Texas Transportation Institute, Texas A\&M University (2002) } \\
\hline
\end{tabular}


Figure 1 National Road System: Northwest Macroregion I

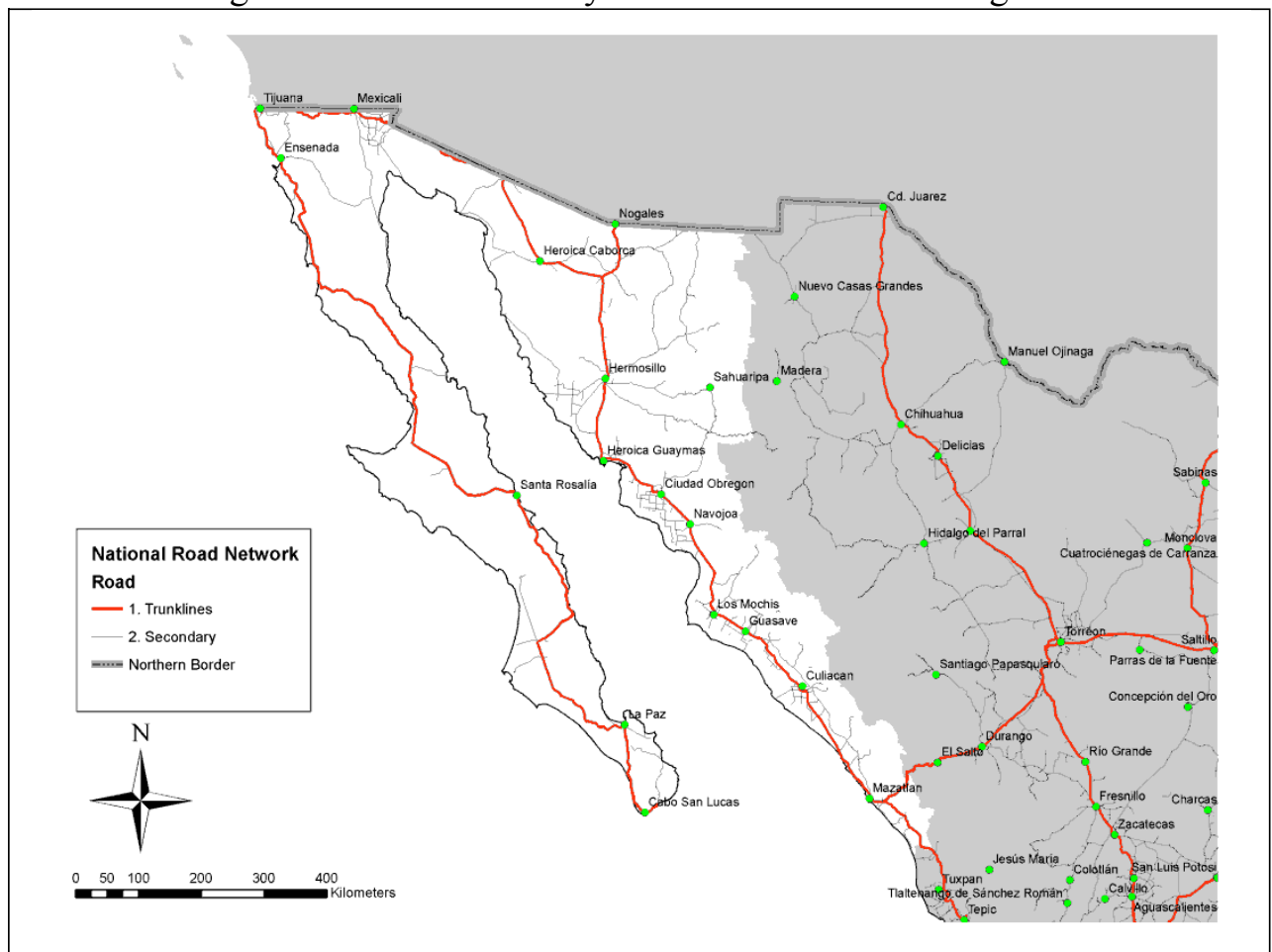

Source: Own elaboration (Digital Cartography from the Municipal Geo-statistical Framework and the Topographic Digital Dataset, INEGI)

Figure 2 National Road System: North Centre Macroregion II

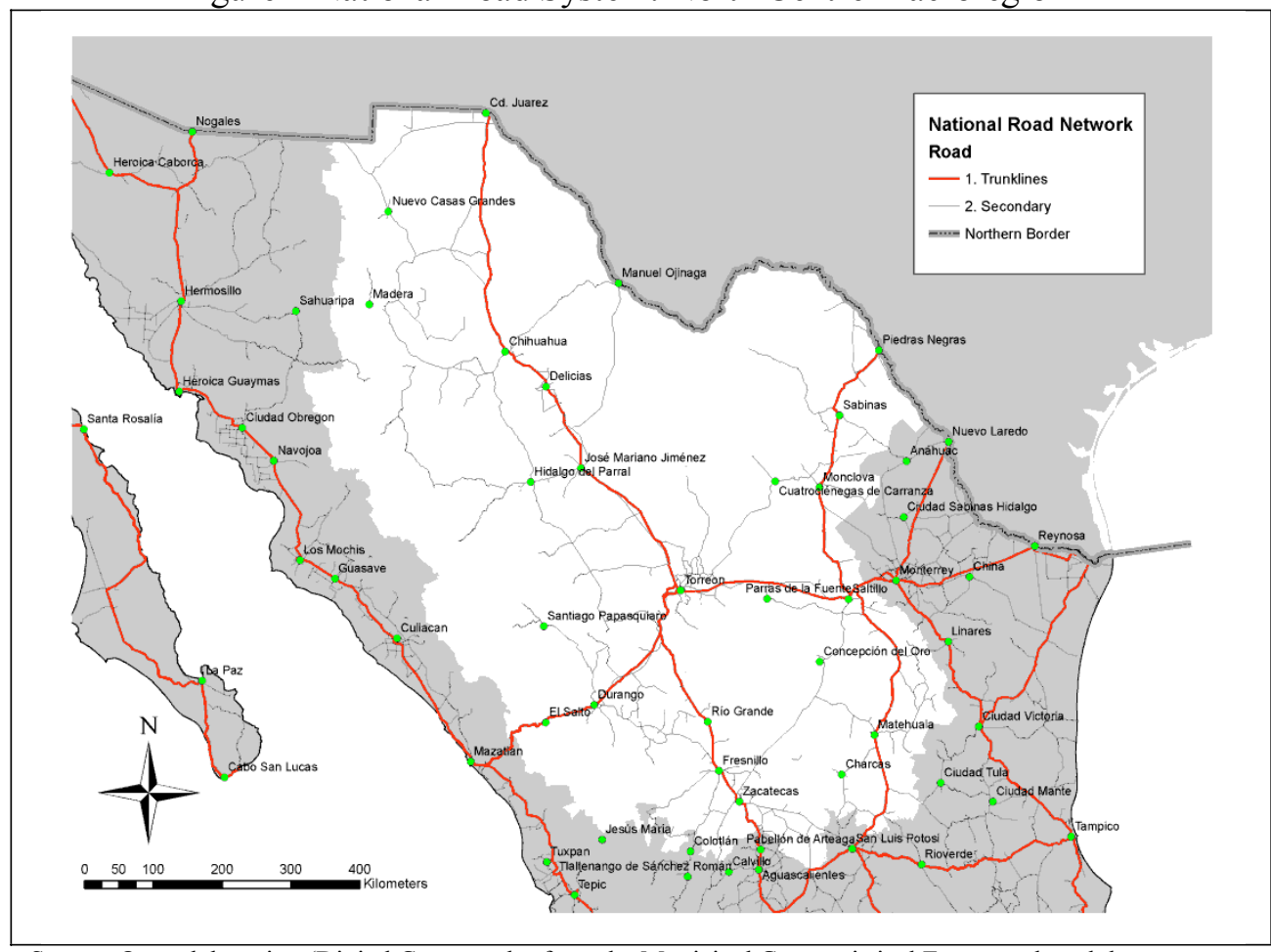

Source: Own elaboration (Digital Cartography from the Municipal Geo-statistical Framework and the Topographic Digital Dataset, INEGI) 
Figure 3 National Road System: Northeast Macroregion III

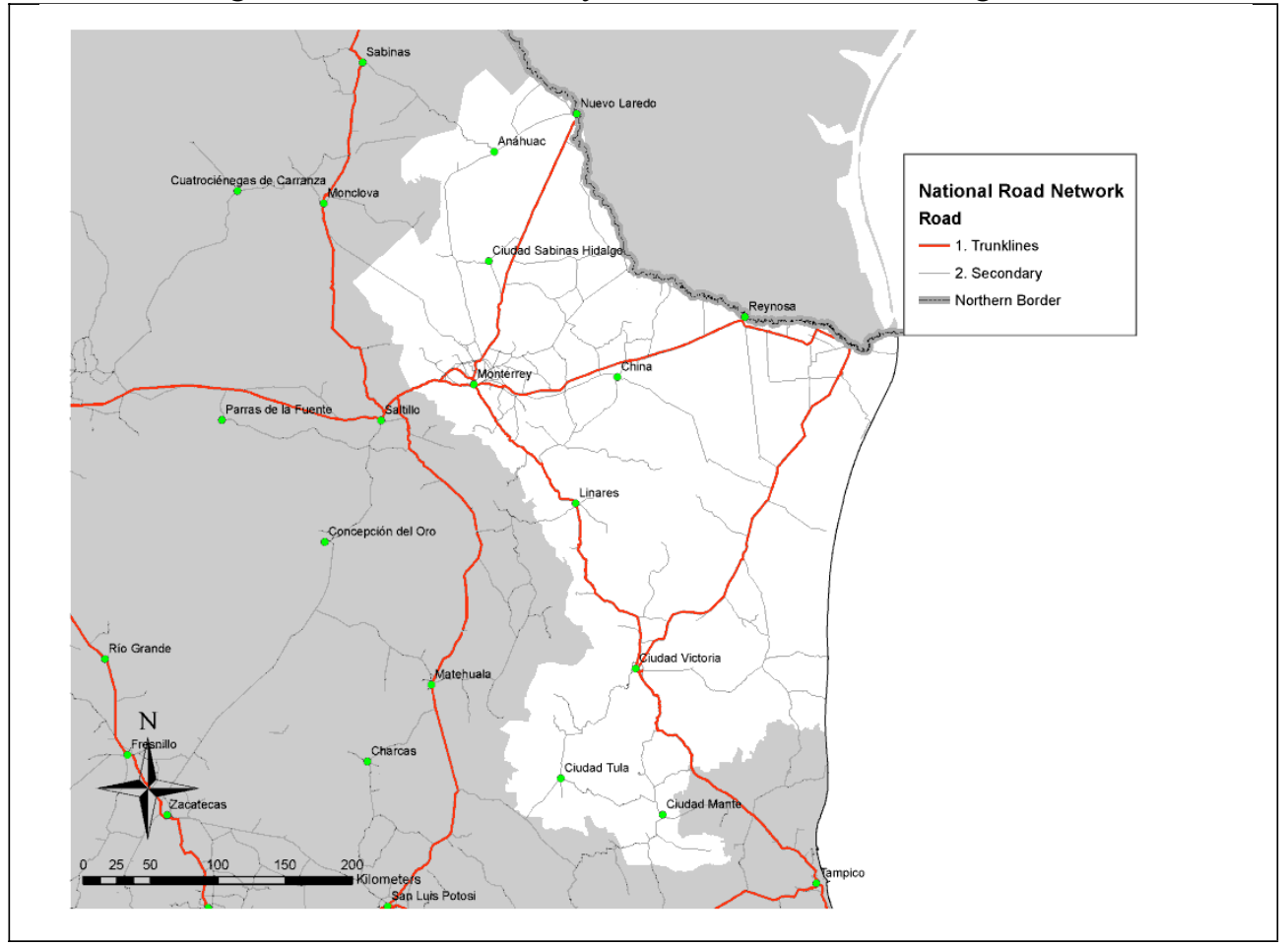

Source: Own elaboration (Digital Cartography from the Municipal Geo-statistical Framework and the Topographic Digital Dataset, INEGI)

Figure 4 National Road System: West Macroregion IV

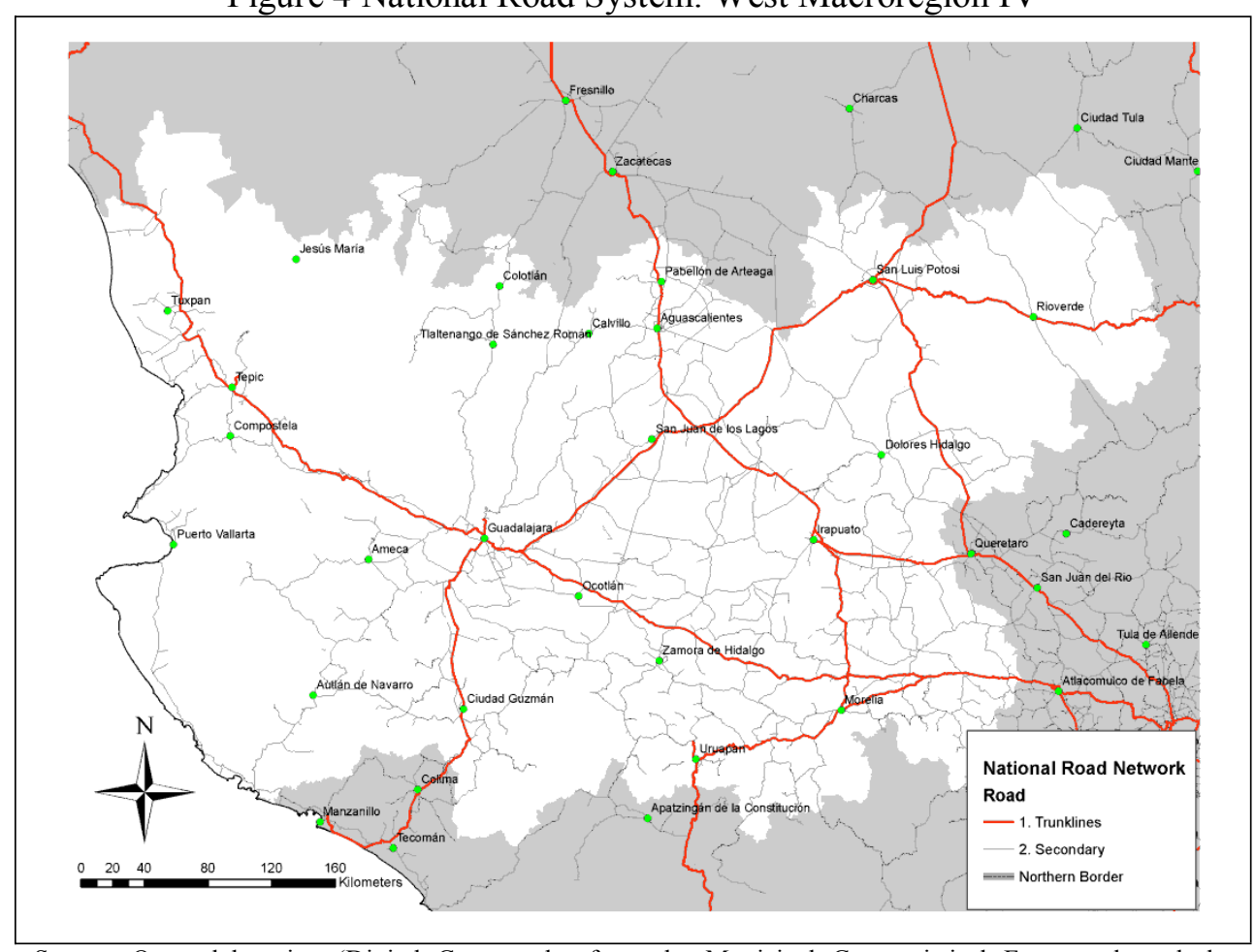

Source: Own elaboration (Digital Cartography from the Municipal Geo-statistical Framework and the Topographic Digital Dataset, INEGI) 
Figure 5 National Road System: Centre Macroregion V

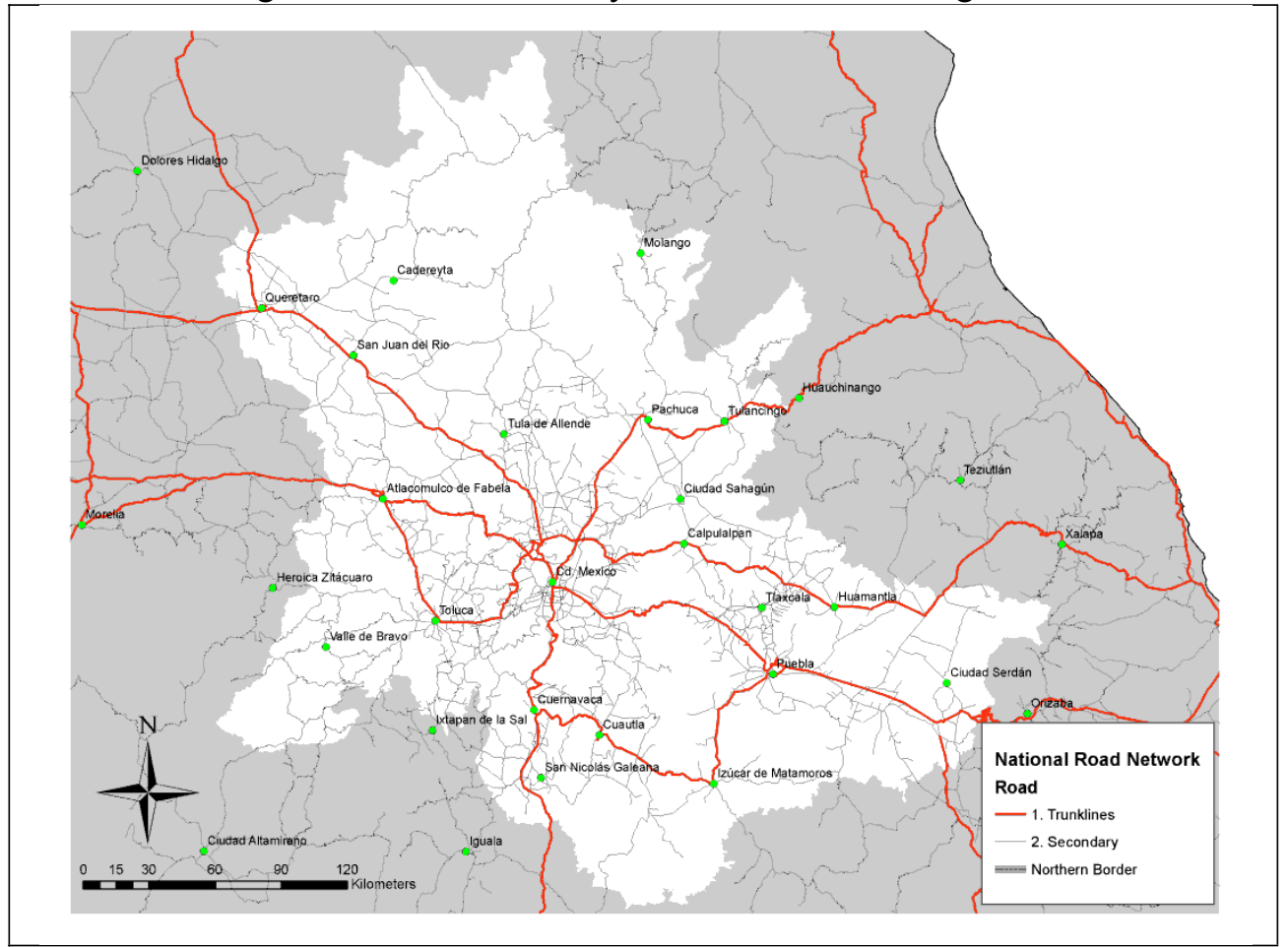

Source: Own elaboration (Digital Cartography from the Municipal Geo-statistical Framework and the Topographic Digital Dataset, INEGI)

Figure 6 National Road System: South Macroregion VI

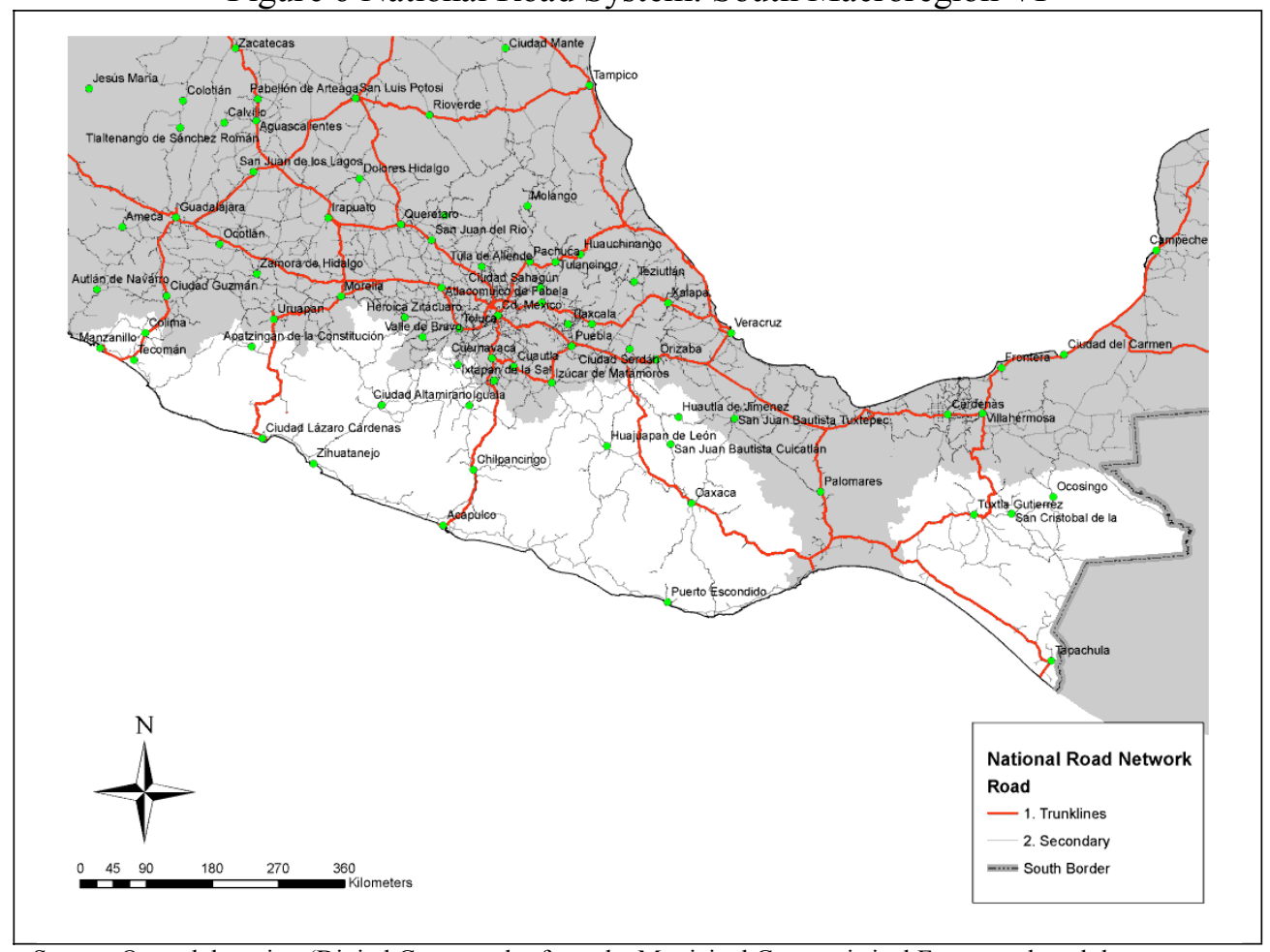

Source: Own elaboration (Digital Cartography from the Municipal Geo-statistical Framework and the Topographic Digital Dataset, INEGI) 
Figure 7 National Road System: East Macroregion VII

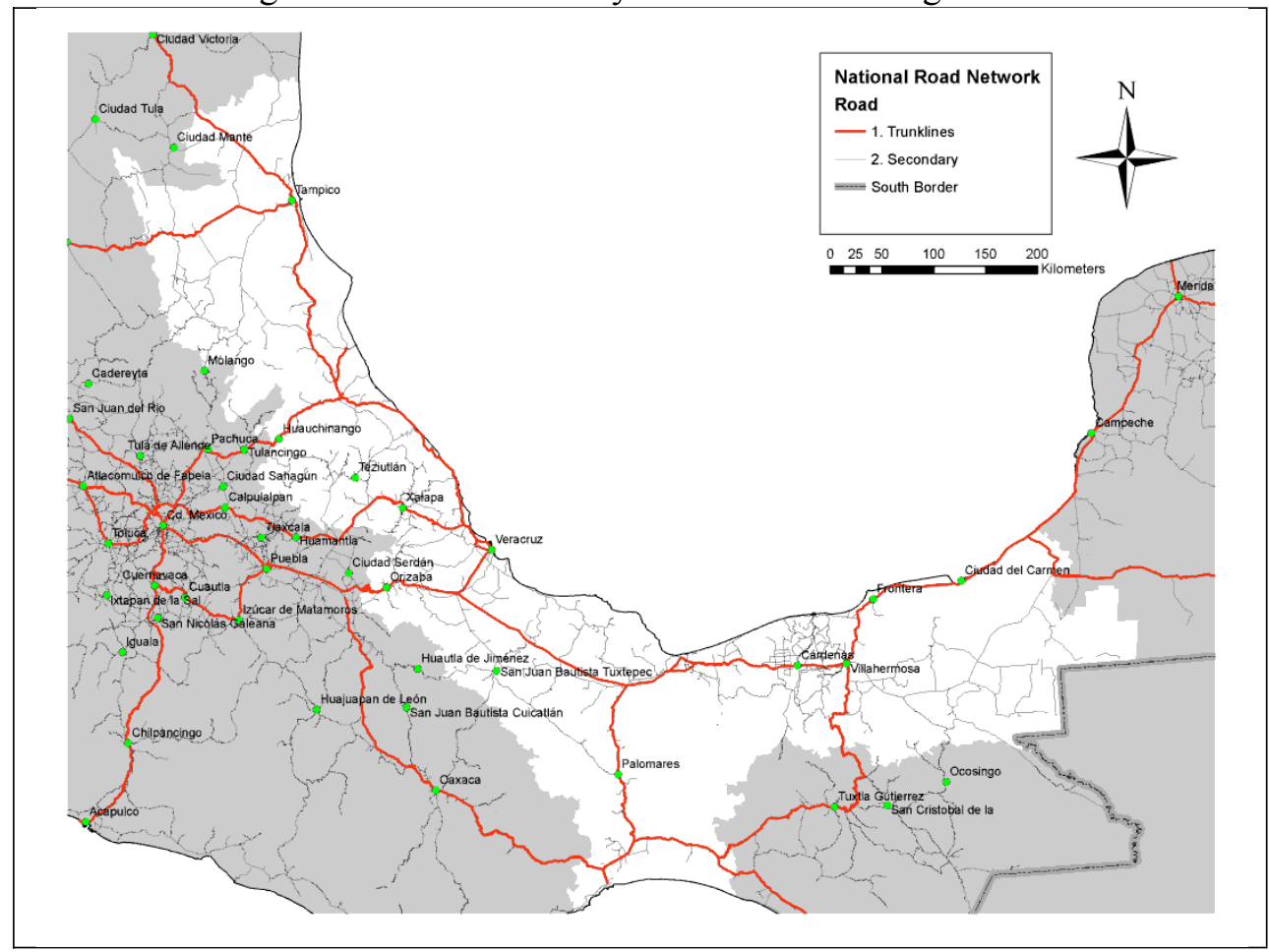

Source: Own elaboration (Digital Cartography from the Municipal Geo-statistical Framework and the Topographic Digital Dataset, INEGI)

Figure 8 National Road System: Yucatan Peninsula Macroregion VIII

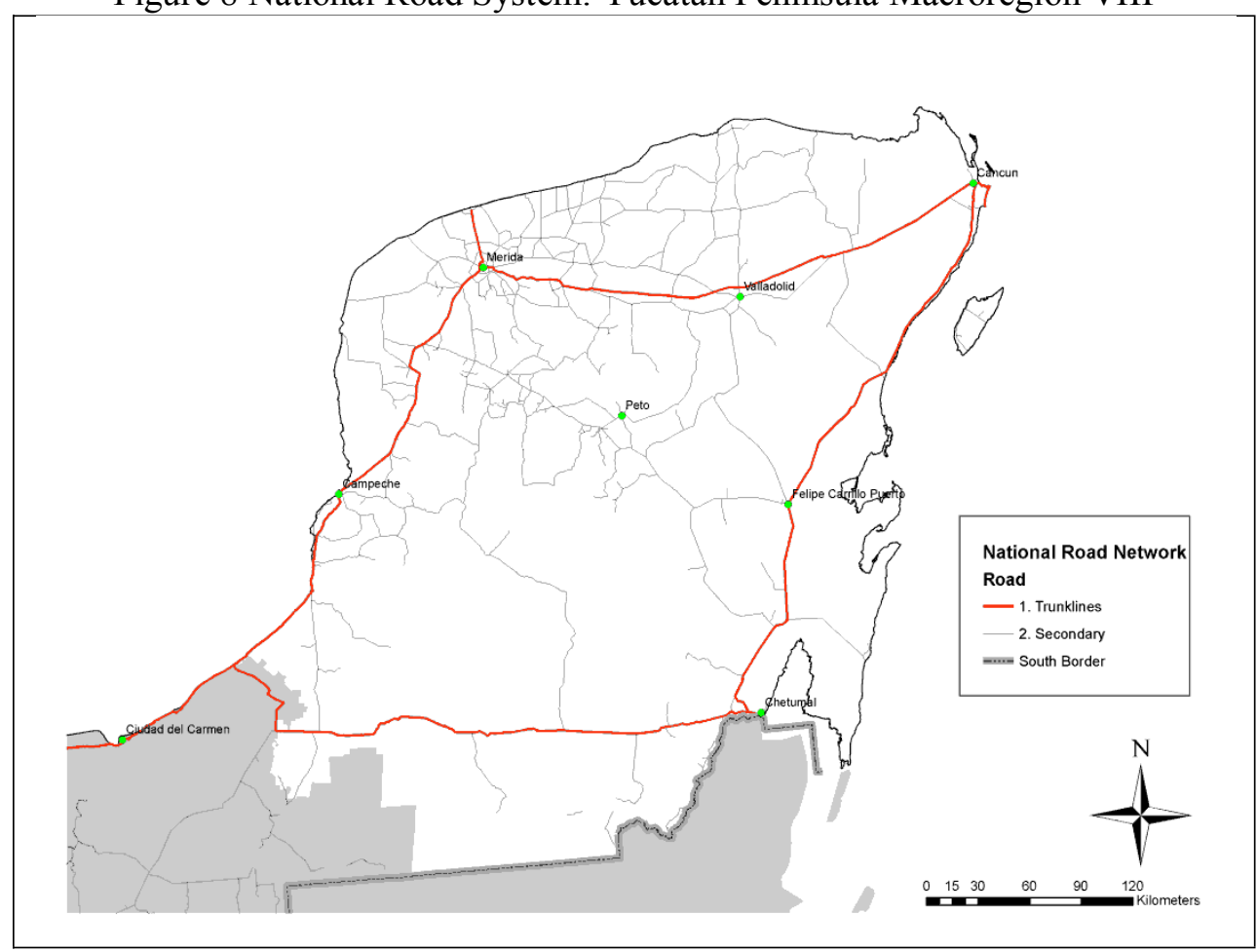

Source: Own elaboration (Digital Cartography from the Municipal Geo-statistical Framework and the Topographic Digital Dataset, INEGI) 
Figure 9 Average Speed on National Corridors Toll Roads

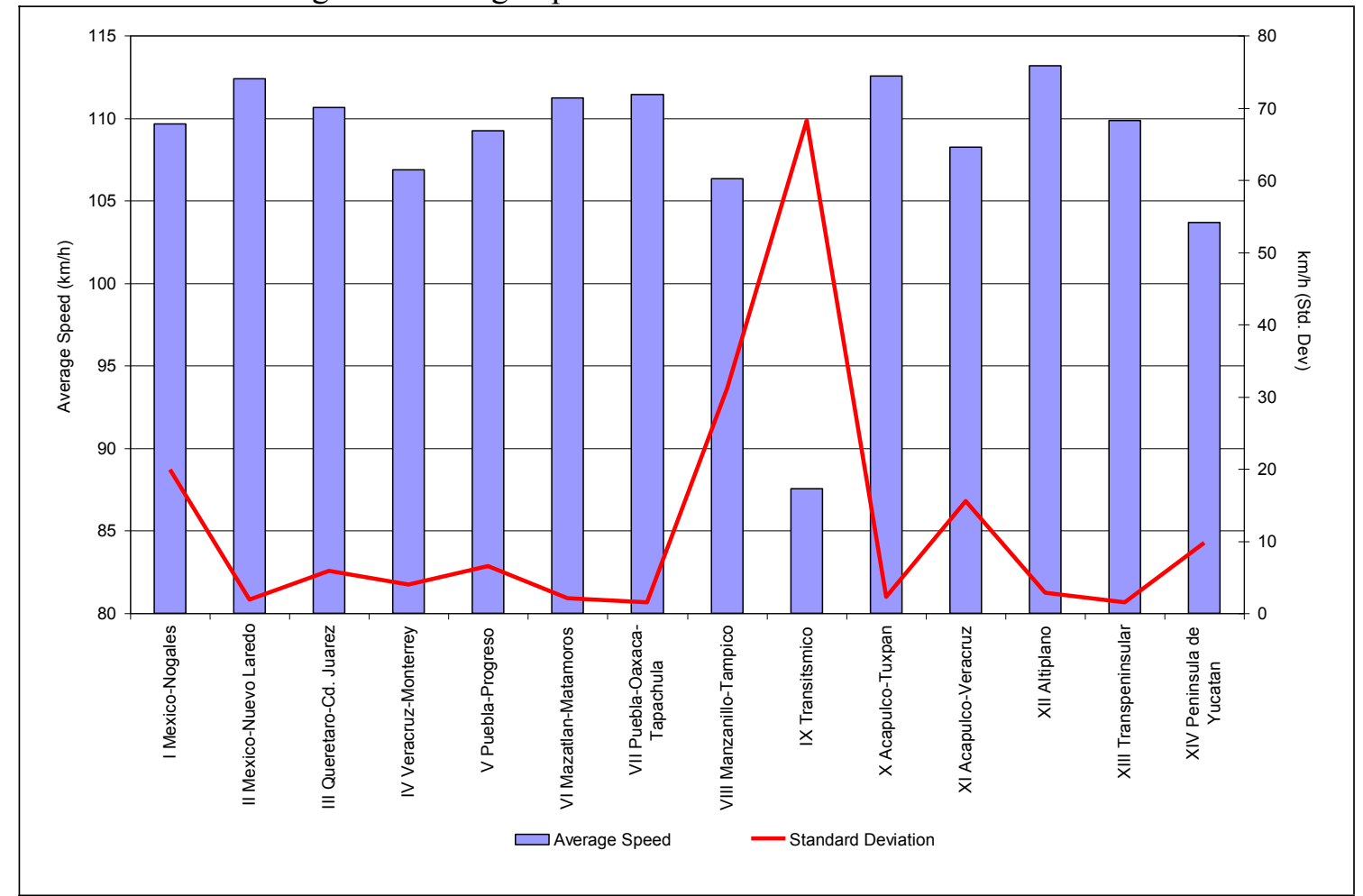

Source: Own elaboration

Figure 10 Average Speed on National Corridors. Toll-Free

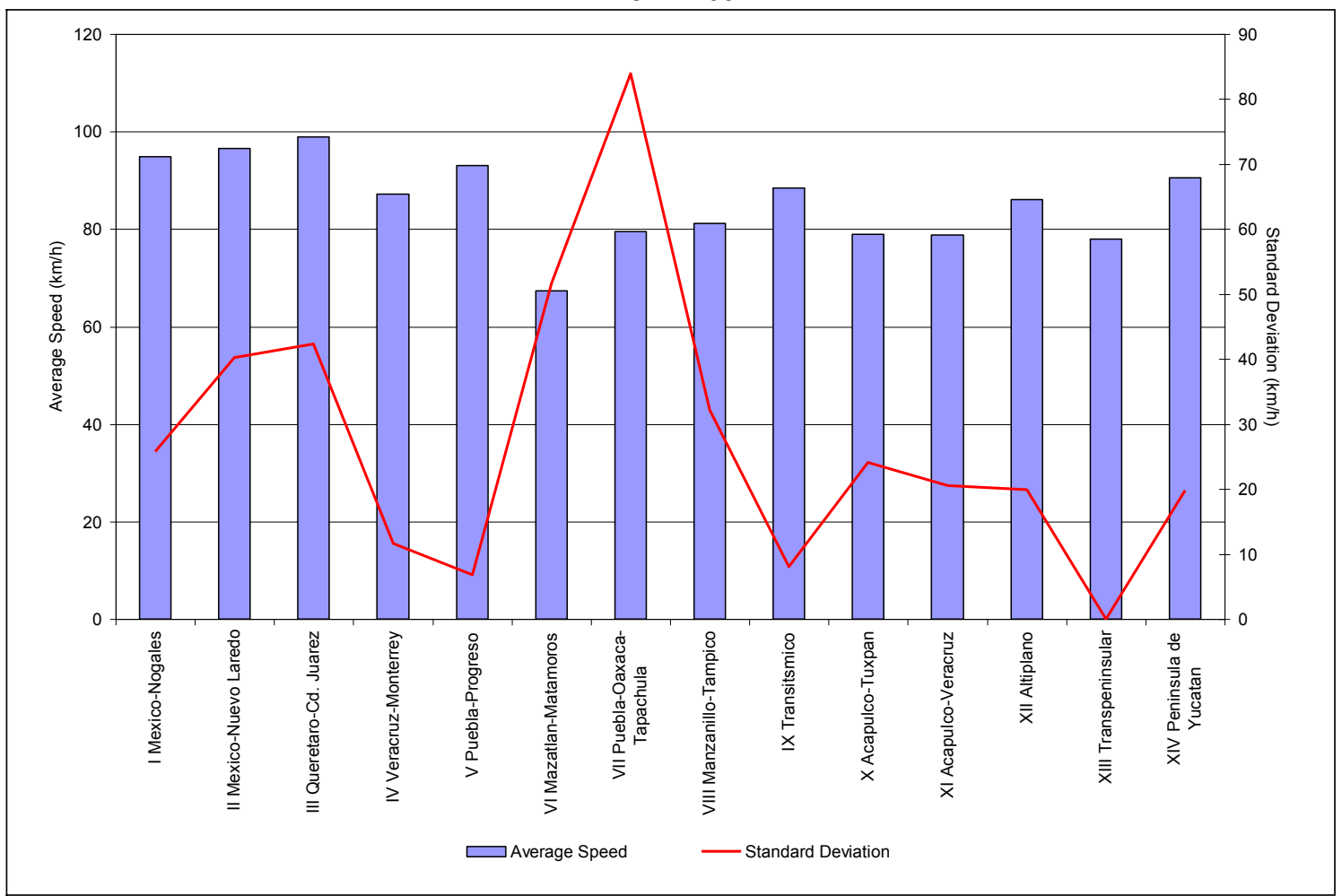

Source: Own elaboration 
Figure 11. Average Speed on Secondary Network by Macroregion Sample

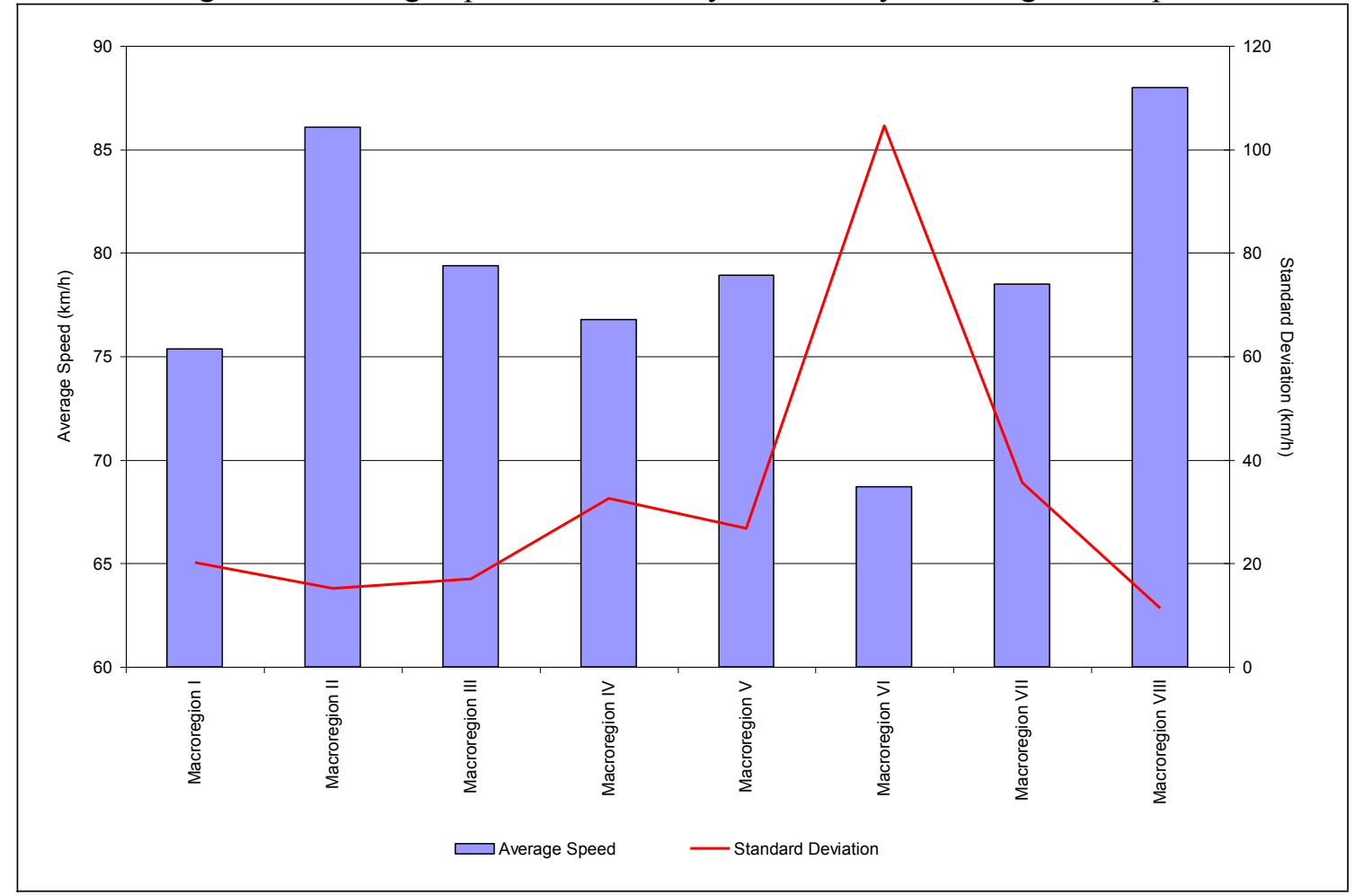

Source: Own elaboration

Figure 12 International Ports of Entry.

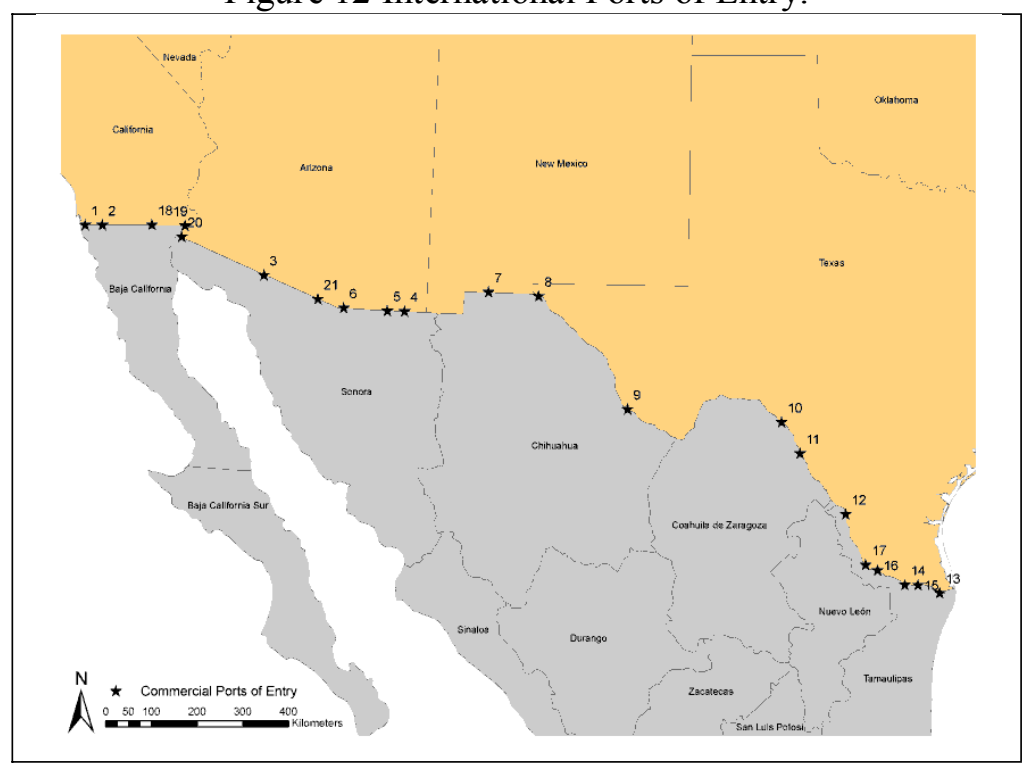

Source: Own elaboration based on the Secretary of Foreign Affairs, Secretary of

Communications and Transport, and USA Department of Transport (Digital

Cartography from the Municipal Geo-statistical Framework and the Topographic

Digital Dataset, INEGI and the National Transportation Atlas Database, BTS) 
Table A.1 Mexico States

Nomenclature of Territorial Unit for Statistics NUTS2

\begin{tabular}{lll}
\hline \hline Code & State & \\
\hline \hline S101 & AGS & Aguascalientes \\
S102 & BCN & Baja California \\
S103 & BCS & Baja California Sur \\
S104 & CAMP & Campeche \\
S105 & COAH & Coahuila \\
S106 & COL & Colima \\
S107 & CHIS & Chiapas \\
S108 & CHIH & Chihuahua \\
S109 & DF & Distrito Federal \\
S110 & DGO & Durango \\
S111 & GTO & Guanajuato \\
S112 & GRO & Guerrero \\
S113 & HDG & Hidalgo \\
S114 & JAL & Jalisco \\
S115 & MEX & México \\
S116 & MICH & Michoacán \\
S117 & MOR & Morelos \\
S118 & NAY & Nayarit \\
S119 & NL & Nuevo Leon \\
S120 & OAX & Oaxaca \\
S121 & PUE & Puebla \\
S122 & QRO & Querétaro \\
S123 & QROO & Quintana Roo \\
S124 & SLP & San Luis Potosi \\
S125 & SIN & Sinaloa \\
S126 & SON & Sonora \\
S127 & TAB & Tabasco \\
S128 & TAM & Tamaulipas \\
S129 & TLAX & Tlaxcala \\
S130 & VER & Veracruz-Llave \\
S131 & YUC & Yucatán \\
S132 & ZAC & Zacatecas \\
\hline \hline & &
\end{tabular}


Table A.2 USA States

Nomenclature of Territorial Unit for Statistics NUTS2

\begin{tabular}{llllll}
\hline \hline Code & State & Code & State & \\
\hline \hline S201 & AL & Alabama & S230 & MT & Montana \\
S202 & AK & Alaska & S231 & NE & Nebraska \\
S204 & AZ & Arizona & S232 & NV & Nevada \\
S205 & AR & Arkansas & S233 & NH & New Hampshire \\
S206 & CA & California & S234 & NJ & New Jersey \\
S208 & CO & Colorado & S235 & NM & New Mexico \\
S209 & CT & Connecticut & S236 & NY & New York \\
S210 & DE & Delaware & S237 & NC & North Carolina \\
S211 & DC & District of Columbia & S238 & ND & North Dakota \\
S212 & FL & Florida & S239 & OH & Ohio \\
S213 & GA & Georgia & S240 & OK & Oklahoma \\
S215 & HI & Hawaii & S241 & OR & Oregon \\
S216 & ID & Idaho & S242 & PA & Pennsylvania \\
S217 & IL & Illinois & S244 & RI & Rhode Island \\
S218 & IN & Indiana & S245 & SC & South Carolina \\
S219 & IA & Iowa & S246 & SD & South Dakota \\
S220 & KS & Kansas & S247 & TN & Tennessee \\
S221 & KY & Kentucky & S248 & TX & Texas \\
S222 & LA & Louisiana & S249 & UT & Utah \\
S223 & ME & Maine & S250 & VT & Vermont \\
S224 & MD & Maryland & S251 & VA & Virginia \\
S225 & MA & Massachusetts & S253 & WA & Washington \\
S226 & MI & Michigan & S254 & WV & West Virginia \\
S227 & MN & Minnesota & S255 & WI & Wisconsin \\
S228 & MS & Mississippi & S256 & WY & Wyoming \\
S229 & MO & Missouri & & & \\
\hline \hline & & & & & \\
\hline
\end{tabular}


Table A.3 Mexico's Regions NUTS3

\begin{tabular}{|c|c|c|c|}
\hline Code & Region & Code & Region \\
\hline R1001 & Calvillo & R1040 & Ciudad Sahagun y Apan \\
\hline R1002 & Pabellon y Tepezala & R1041 & Jacala y Molango \\
\hline R1003 & Sur de Aguascalientes & R1042 & Pachuca \\
\hline R1004 & Ensenada & R1043 & Tulancingo \\
\hline R1005 & Tijuana & R1044 & Valle del Mezquital y Tula \\
\hline \multirow[t]{2}{*}{$\mathrm{R} 1006$} & Desierto de Vizcaino y Santa Rosalia & R1045 & Ameca \\
\hline & & R1046 & Costa Sur de Jalisco y Autlan \\
\hline R1007 & Valle de Santo Domingo y La Paz & R1047 & Guadalajara \\
\hline R1008 & Valle del Sur BCS & R1048 & Los Altos \\
\hline R1009 & Campeche y Champoton & R1049 & Norte de Jalisco \\
\hline $\mathrm{R} 1010$ & Ciudad del Carmen & $\mathrm{R} 1050$ & Ocotlan y La Barca \\
\hline $\mathrm{R} 1011$ & Monclava & R1051 & Puerto Vallarte \\
\hline $\mathrm{R} 1012$ & Nueva Rosita y Muzquiz & $\mathrm{R} 1052$ & Sur de Jalisco \\
\hline $\mathrm{R} 1013$ & Parras & R1053 & Noroeste de Estado de Mexico y \\
\hline R1014 & Piedras Negras y Acuna & & Atlacomulco \\
\hline $\mathrm{R} 1015$ & Saltillo & R1054 & Sur del Estado de Mexico \\
\hline R1016 & Sierra Mojada y Cuatro Cienagas & R1055 & Toluca y Lerma \\
\hline R1017 & Manzanillo & R1056 & Valle de Bravo \\
\hline R1018 & Noreste de Colima & R1057 & Cienagas de Chapala y Zamora \\
\hline R1019 & Tecoman & R1058 & Costa de Michoacan y Lazaro \\
\hline \multirow[t]{2}{*}{$\mathrm{R} 1020$} & Altos de Chapas y San Cristobal de & & Cardenas \\
\hline & Las Casas & R1059 & Meseta Purepecha y Uruapan \\
\hline \multirow[t]{2}{*}{$\mathrm{R} 1021$} & Centro de Chiapas y Tuxtla Gutierrez & R1060 & Morelia \\
\hline & & R1061 & Noreste de Michoacan \\
\hline R1022 & Comitan y Lacandonia & R1062 & Valle de Apatzingan \\
\hline R1023 & Costa de Chiapas y Soconusco & R1063 & Cuautla \\
\hline R1024 & Allende y Jimenez & R1064 & Cuernavaca \\
\hline $\mathrm{R} 1025$ & Casas Grandes & R1065 & Puente de Ixtla y Zacatepec \\
\hline $\mathrm{R} 1026$ & Parral & R1066 & Centro de Nayarit y Tepic \\
\hline R1027 & Sierra Traumara & R1067 & Norte de Nayarit \\
\hline $\mathrm{R} 1028$ & Valle de Delicias & R1068 & Sierra de Nayarit \\
\hline R1029 & Valle de Juarez & R1069 & Sur de Nayarit \\
\hline R1030 & Valle del Bajo Conchos y Ojinaga & $\mathrm{R} 1070$ & Anahuac y Sabinas de Hidalgo \\
\hline R1031 & Valle del Centro de Chihuahua & R1071 & Cerralvo \\
\hline R1032 & Sierra Norte de Durango & R1072 & China \\
\hline R1033 & Sierra Sur de Durango & R1073 & Linares y Montemorelos \\
\hline R1034 & Valle del Centro de Durango & R1074 & Monterrey \\
\hline R1035 & Norte de Guanajuato & R1075 & Costa de Oaxaca \\
\hline R1036 & Acapulco & R1076 & La Canada \\
\hline R1037 & Centro de Guerrero y Chilpancingo & R1077 & Papaloapan \\
\hline R1038 & Ixtapa y Zihuatanejo & R1078 & Valle Central \\
\hline R1039 & Norte de Guerrero e Iguala & R1079 & Izucar de Matamoros \\
\hline
\end{tabular}


Table A.3 Mexico Regions (continuation)

\begin{tabular}{llll}
\hline \hline Code & Region & Code & Region \\
\hline \hline R1079 & Izucar de Matamoros & R1108 & Jaumave y Tula \\
R1080 & Oriental y Ciudad Serdan & R1109 & Nuevo Laredo \\
R1081 & Puebla de los Angeles y Atlixco & R1110 & Calpulalpan \\
R1082 & Sierra Norte de Puebla & R1111 & Huamantla \\
R1083 & Teziutlan & R1112 & Tlaxcala y Apizaco \\
R1084 & Ciudad de Queretaro & R1113 & Jalapa y Martinez de la Torre \\
R1085 & Norte de Queretaro y Cadereyta & R1114 & Orizaba y Cordoba \\
R1086 & San Juan del Rio & R1115 & Puerto de Veracruz \\
R1087 & Carrillo Puerto & R1116 & Peto \\
R1088 & Chetumal & R1117 & Valladolid \\
R1089 & Charcas & R1118 & Centro de Zacatecas \\
R1090 & Rioverde y Ciudad del Maiz & R1119 & Fresnillo y Sombrerete \\
R1091 & Suroeste de San Luis & R1120 & Norte de Zacatecas \\
R1092 & Culiacan y Valle del Centro de & R1121 & Rio Grande \\
& Sinaloa & R1122 & Valles de Juchipila y Tlaltenango \\
R1093 & Guasave y Guamuchil & R1123 & Cancun y Tizimin \\
R1094 & Los Mochis & R1124 & Region del Centro y Villahermosa y \\
R1095 & Valle de Sinaloa y Mazatlan & & Norte de Chiapas \\
R1096 & Caborca y Altar & R1125 & Comarca Lagunera \\
R1097 & Ciudad Obregon & R1126 & Cuenca de Mexico \\
R1098 & Costa de Sonora y Hermosillo & R1127 & Dr. Arroyo Galeana y Salado de San \\
R1099 & Guaymas & & Luis y Matehuala \\
R1100 & Montana de Sonora & R1128 & Bajio \\
R1101 & Navojoa & R1129 & Itsmo de Tehuantepec \\
R1102 & Nogales y Cananea & R1130 & La Mixteca \\
R1103 & La Chontalpa y Cardenas & R1131 & Las Huastecas \\
R1104 & Los Rios & R1132 & Valle de Mexicali, Tecate y San Luis \\
R1105 & Bravo Bajo Matamoros & & Rio Colorado \\
R1106 & Centro de Tamaulipas y Ciudad & R1133 & Papaloapan \\
& Victoria & R1134 & Region Henequenera \\
R1107 & El Mante & R1135 & Tierra Caliente \\
\hline \hline Based on INEGI (2000a, 2000c) and Bassols-Batalla $(1993,2002$ & & \\
\cline { 3 - 4 } & &
\end{tabular}

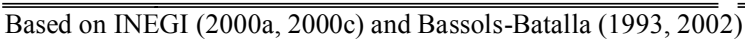


Table A.4 USA's Regions NUTS3

\begin{tabular}{|c|c|c|c|}
\hline Code & Region & Code & Region \\
\hline R2001 & Aberdeen & R2041 & $\begin{array}{l}\text { Corpus Christi-Kingsville } \\
\end{array}$ \\
\hline R2002 & Abilene & R2042 & Dallas-Fort Worth \\
\hline R2003 & Albany & R2043 & Davenport-Moline-Rock Island \\
\hline R2004 & Albany-Schenectady-Amsterdam & R2044 & Dayton-Springfield-Greenville \\
\hline R2005 & Albuquerque & R2045 & Denver-Aurora-Boulder \\
\hline R2006 & Alpena & R2046 & Des Moines-Newton-Pella \\
\hline R2007 & Amarillo & $\mathrm{R} 2047$ & Detroit-Warren-Flint \\
\hline R2008 & Anchorage & $\mathrm{R} 2048$ & Dothan-Enterprise-Ozark \\
\hline R2009 & Appleton-Oshkosh-Neenah & R2049 & Dover \\
\hline R2010 & Asheville-Brevard & $\mathrm{R} 2050$ & Duluth \\
\hline R2011 & Atlanta-Sandy Springs-Gainesville & $\mathrm{R} 2051$ & El Paso \\
\hline R2012 & Augusta-Richmond County & $\mathrm{R} 2052$ & Erie \\
\hline R2013 & Austin-Round Rock & $\mathrm{R} 2053$ & Eugene-Springfield \\
\hline R2014 & Bangor & $\mathrm{R} 2054$ & Evansville \\
\hline R2015 & Baton Rouge-Pierre Part & $\mathrm{R} 2055$ & Fargo-Wahpeton \\
\hline R2016 & Beaumont-Port Arthur & $\mathrm{R} 2056$ & Farmington \\
\hline R2017 & Bend-Prineville & $\mathrm{R} 2057$ & Fayetteville-Springdale-Rogers \\
\hline R2018 & Billings & $\mathrm{R} 2058$ & Flagstaff \\
\hline R2019 & Birmingham-Hoover-Cullman & $\mathrm{R} 2059$ & Fort Smith \\
\hline R2020 & Bismarck & $\mathrm{R} 2060$ & Fort Wayne-Huntington-Auburn \\
\hline R2021 & Boise City-Nampa & $\mathrm{R} 2061$ & Fresno-Madera \\
\hline R2022 & Boston-Worcester-Manchester & R2062 & Gainesville \\
\hline R2023 & Buffalo-Niagara-Cattaraugus & R2063 & Grand Forks \\
\hline R2024 & Burlington-South Burlington & R2064 & Grand Rapids-Muskegon-Holland \\
\hline R2025 & Cape Girardeau-Jackson & R2065 & Great Falls \\
\hline R2026 & Casper & R2066 & Greensboro--Winston-Salem--High \\
\hline R2027 & Cedar Rapids & R2067 & Greenville \\
\hline R2028 & Champaign-Urbana & R2068 & Greenville-Spartanburg-Anderson \\
\hline R2029 & Charleston & R2069 & Gulfport-Biloxi-Pascagoula \\
\hline R2030 & Charleston-North Charleston & R2070 & Harrisburg-Carlisle-Lebanon \\
\hline R2031 & Charlotte-Gastonia-Salisbury & $\mathrm{R} 2071$ & Harrisonburg \\
\hline R2032 & Chicago-Naperville-Michigan Cit & $\mathrm{R} 2072$ & Hartford-West Hartford-Williman \\
\hline \multirow[t]{2}{*}{ R2033 } & Cincinnati-Middletown- & $\mathrm{R} 2073$ & Helena \\
\hline & Wilmington & $\mathrm{R} 2074$ & Honolulu \\
\hline R2034 & Clarksburg & R2075 & Houston-Baytown-Huntsville \\
\hline R2035 & Cleveland-Akron-Elyria & R2076 & Huntsville-Decatur \\
\hline R2036 & Colorado Springs & R2077 & Idaho Falls-Blackfoot \\
\hline R2037 & Columbia & R2078 & Indianapolis-Anderson-Columbus \\
\hline R2038 & Columbia-Newberry & R2079 & Jacksonville \\
\hline R2039 & Columbus-Auburn-Opelika & $\mathrm{R} 2080$ & Jackson-Yazoo City \\
\hline R2040 & Columbus-Marion-Chillicothe & & \\
\hline
\end{tabular}


Table A.4 USA Regions (continuation)

\begin{tabular}{ll}
\hline \hline Code & Region \\
\hline \hline R2081 & Johnson City-Kingsport-Bristol \\
R2082 & Jonesboro \\
R2083 & Joplin \\
R2084 & Kansas City-Overland Park-Kansa \\
R2085 & Kearney \\
R2086 & Kennewick-Richland-Pasco \\
R2087 & Killeen-Temple-Fort Hood \\
R2088 & Knoxville-Sevierville-La Follete \\
R2089 & La Crosse \\
R2090 & Lafayette-Acadiana \\
R2091 & Lake Charles-Jennings \\
R2092 & Las Vegas-Paradise-Pahrump \\
R2093 & Lewiston \\
R2094 & Lexington-Fayette--Frankfort--R \\
R2095 & Lincoln \\
R2096 & Little Rock-North Little Rock-P \\
R2097 & Los Angeles-Long Beach- \\
& Riverside \\
R2098 & Louisville-Elizabethtown-Scotts \\
R2099 & Lubbock-Levelland \\
R2100 & Macon-Warner Robins-Fort Valley \\
R2101 & Madison-Baraboo \\
R2102 & Marinette \\
R2103 & Mason City \\
R2104 & McAllen-Edinburg-Pharr \\
R2105 & Memphis \\
R2106 & Miami-Fort Lauderdale-Miami Bea \\
R2107 & Midland-Odessa \\
R2108 & Milwaukee-Racine-Waukesha \\
R2109 & Minneapolis-St. Paul-St. Cloud \\
R2110 & Minot \\
R2111 & Missoula \\
R2112 & Mobile-Daphne-Fairhope \\
R2113 & Monroe-Bastrop \\
R2114 & Montgomery-Alexander City \\
R2115 & Myrtle Beach-Conway- \\
R2116 & Georgetown \\
\hline \hline & Nashville-Davidson--Murfreesbor \\
New Orleans-Metairie-Bogalusa \\
Oklahoma City-Shawnee \\
Rart \\
Rouncil Bluffs-Fremont \\
\hline
\end{tabular}

\begin{tabular}{ll}
\hline \hline Code & Region \\
\hline \hline R2121 & Orlando-The Villages \\
R2122 & Paducah \\
R2123 & Panama City-Lynn Haven \\
R2124 & Pendleton-Hermiston \\
R2125 & Pensacola-Ferry Pass-Brent \\
R2126 & Peoria-Canton \\
R2127 & Philadelphia-Camden-Vineland \\
R2128 & Phoenix-Mesa-Scottsdale \\
R2129 & Pittsburgh-New Castle \\
R2130 & Portland-Lewiston-South Portland \\
R2131 & Portland-Vancouver-Beaverton \\
R2132 & Pueblo \\
R2133 & Raleigh-Durham-Cary \\
R2134 & Rapid City \\
R2135 & Redding \\
R2136 & Reno-Sparks \\
R2137 & Richmond \\
R2138 & Roanoke \\
R2139 & Rochester-Batavia-Seneca Falls \\
R2140 & Sacramento--Arden-Arcade--Truck \\
R2141 & Salina \\
R2142 & Salt Lake City-Ogden-Clearfield \\
R2143 & San Angelo \\
R2144 & San Antonio \\
R2145 & San Diego-Carlsbad-San Marcos \\
R2146 & San Jose-San Francisco-Oakland \\
R2147 & Santa Fe-Espanola \\
R2148 & Sarasota-Bradenton-Venice \\
R2149 & Savannah-Hinesville-Fort Stewart \\
R2150 & Scotts Bluff \\
R2151 & Scranton--Wilkes-Barre \\
R2152 & Seattle-Tacoma-Olympia \\
R2153 & Shreveport-Bossier City-Minden \\
R2154 & Sioux City-Vermillion \\
R2155 & Sioux Falls \\
R2156 & South Bend-Mishawaka \\
R2157 & Spokane \\
R2158 & Springfield \\
R2159 & Springfield \\
R2160 & St. Louis-St. Charles-Farmington \\
\hline \hline &
\end{tabular}


Table A.4 USA Regions (continuation)

\begin{tabular}{lllll}
\cline { 2 - 3 } Code & Region & Code & Region \\
\hline \hline R2161 & State College & R2171 & Tupelo \\
R2162 & Syracuse-Auburn & & R2172 & Twin Falls \\
R2163 & Tallahassee & & R2173 & Virginia Beach-Norfolk-Newport \\
R2164 & Tampa-St. Petersburg-Clearwater & & R2174 & Washington-Baltimore-Northern V \\
R2165 & Texarkana & & R2175 & Waterloo-Cedar Falls \\
R2166 & Toledo-Fremont & R2176 & Wausau-Merrill \\
R2167 & Topeka & R2177 & Wenatchee \\
R2168 & Traverse City & R2178 & Wichita Falls \\
R2169 & Tucson & R2179 & Wichita-Winfield \\
R2170 & Tulsa-Bartlesville & & \\
\hline \hline
\end{tabular}

Based on Bureau of Economic Analysis (2004a) and Bureau of Transportation Statistics (2006)

Figure A.1 Macroregions: Mexico

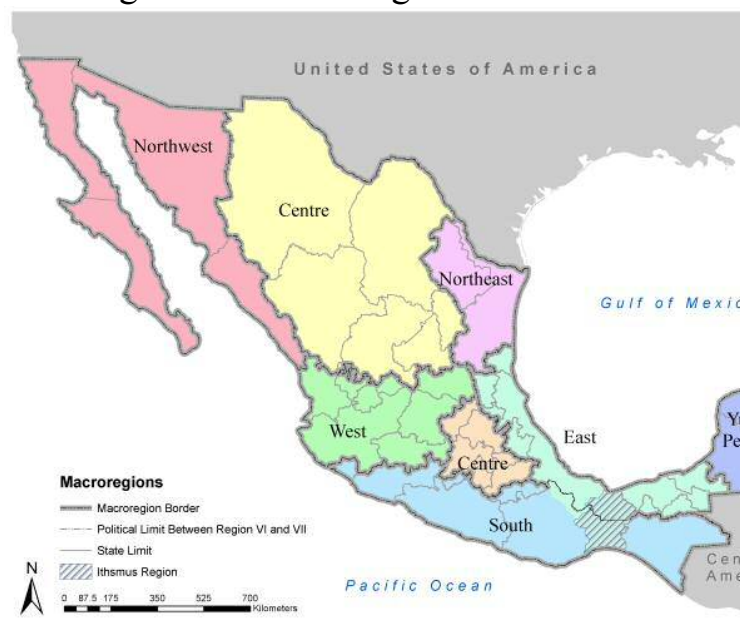

Figure A.2 Macroregions: USA

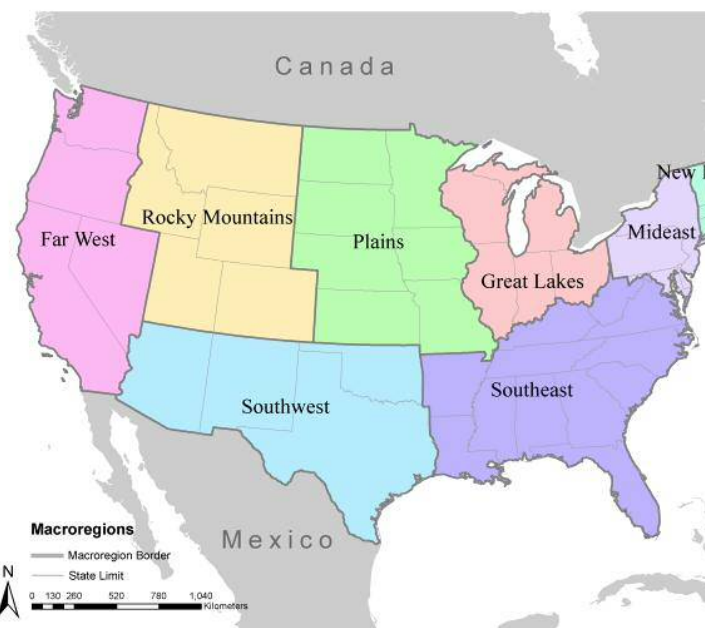

Source: Own elaboration based on the Bureau of Economic Analysis (2004b) (Digital Cartography the National

Transportation Atlas Database, BTS)
Source: Own elaboration based on Bassols-Batalla (1993, 2002) (Digital Cartography from the Municipal Geo-statistical Framework and the Topographic Digital Dataset) 
Figure A.3 Regionalisation: Mexico, Northwest

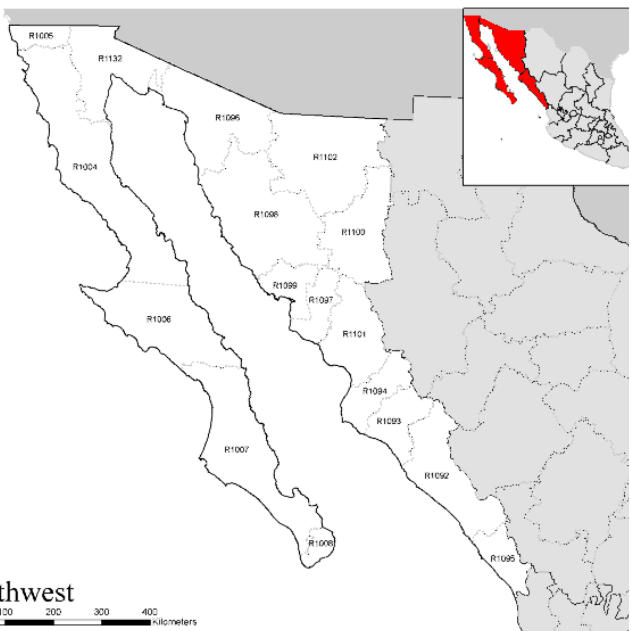

Source: Own elaboration based on Bassols-Batalla (1993, 2002) (Digital Cartography from the Municipal Geo-statistical Framework and the Topographic Digital Dataset)

Figure A.5 Regionalisation: Mexico, Northeast

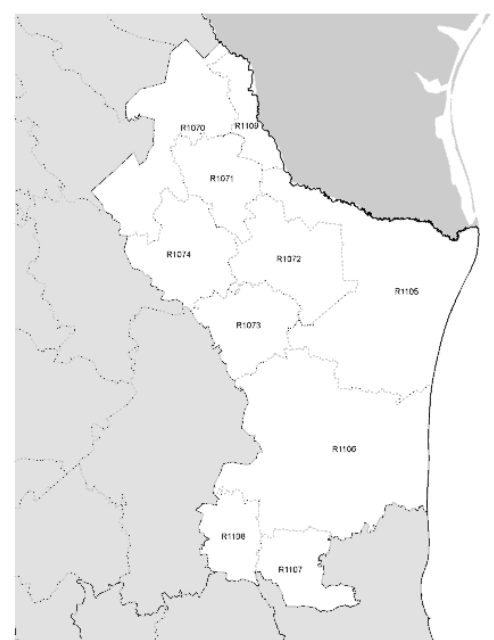

$\bigwedge^{N}$ North East

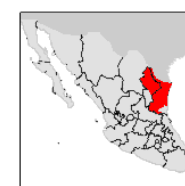

$\Lambda^{N}$ North Centre

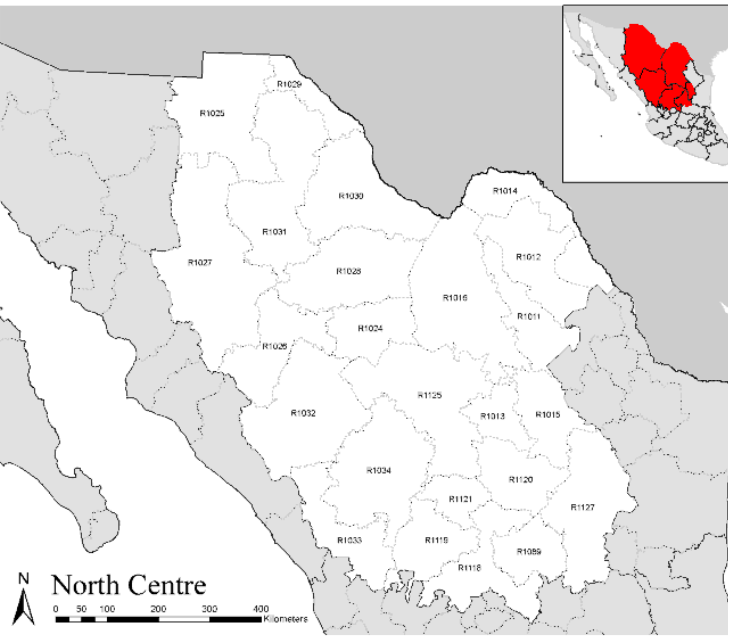

Source: Own elaboration based on Bassols-Batalla (1993, 2002) (Digital Cartography from the Municipal Geo-statistical Framework and the Topographic Digital Dataset)

Figure A.6 Regionalisation: Mexico, West

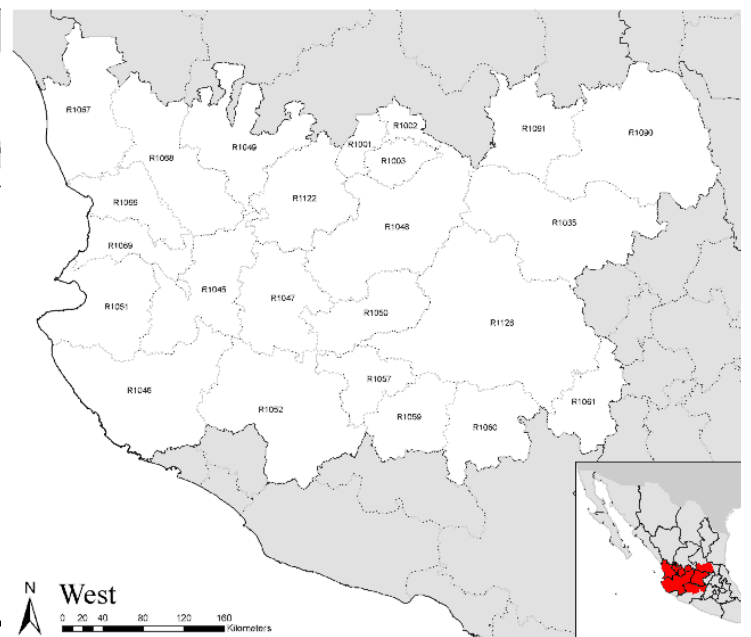

Source: Own elaboration based on Bassols-Batalla (1993, 2002) (Digital Cartography from the Municipal Geo-statistical Framework and the Topographic Digital Dataset)
Source: Own elaboration based on Bassols-Batalla (1993, 2002) (Digital Cartography from the Municipal Geo-statistical Framework and the Topographic Digital Dataset) 
Figure A.7 Regionalisation: Mexico, Centre

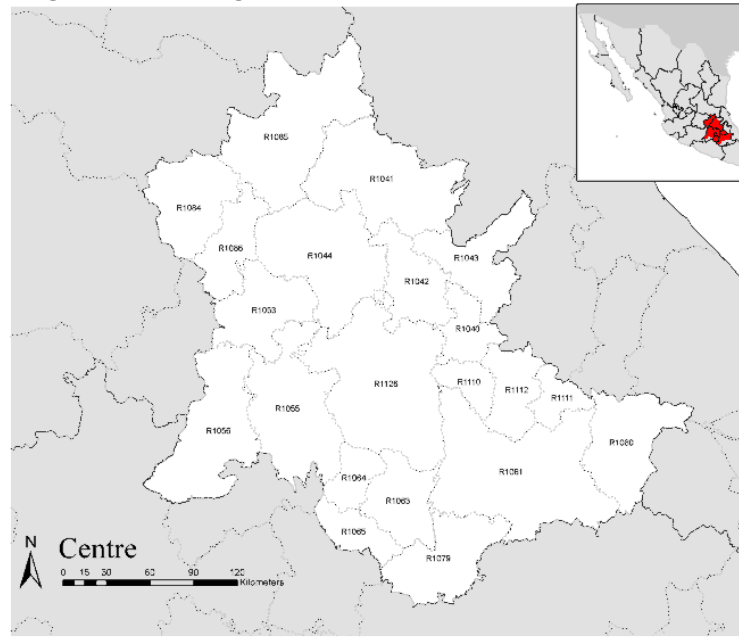

Source: Own elaboration based on Bassols-Batalla (1993,

2002) (Digital Cartography from the Municipal Geo-statistical Framework and the Topographic Digital Dataset)

Figure A.9 Regionalisation: Mexico, East

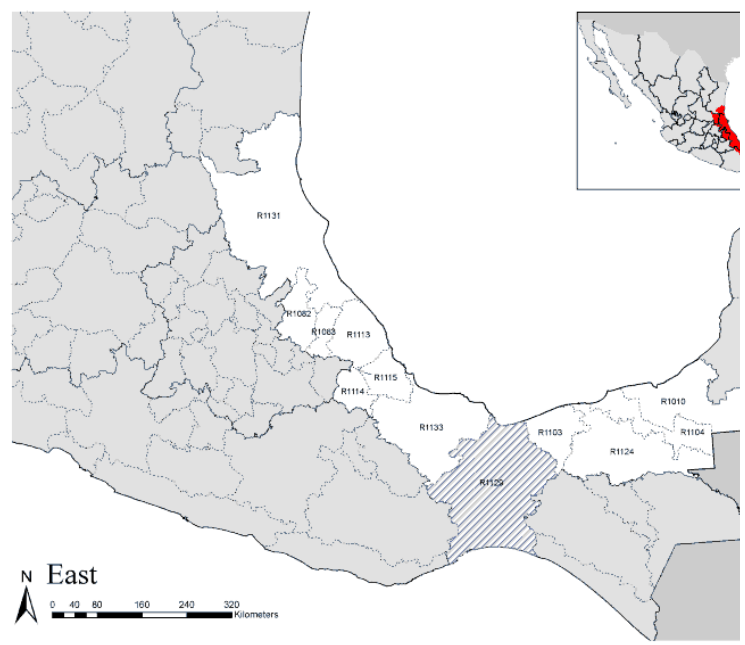

Source: Own elaboration based on Bassols-Batalla (1993,

2002) (Digital Cartography from the Municipal Geo-statistical Framework and the Topographic Digital Dataset)
Figure A.8 Regionalisation: Mexico, South

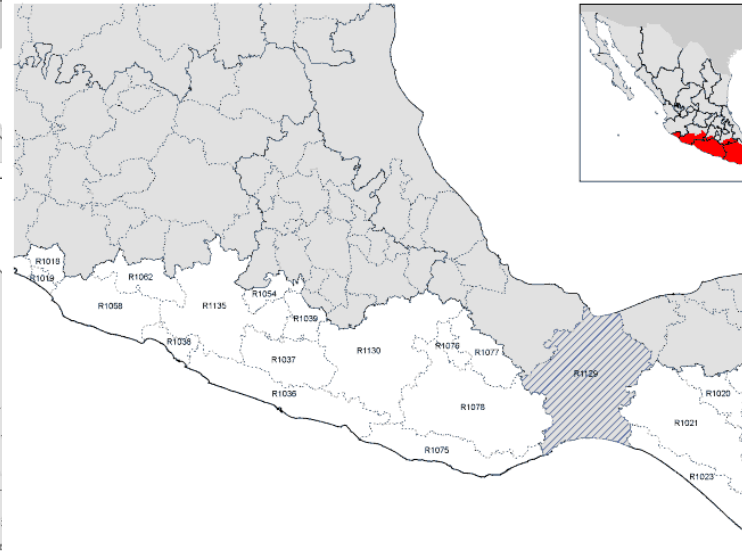

N South

Source: Own elaboration based on Bassols-Batalla (1993,

2002) (Digital Cartography from the Municipal Geo-statistical Framework and the Topographic Digital Dataset)

Figure A.10 Regionalisation: Mexico, Yucatan Peninsula

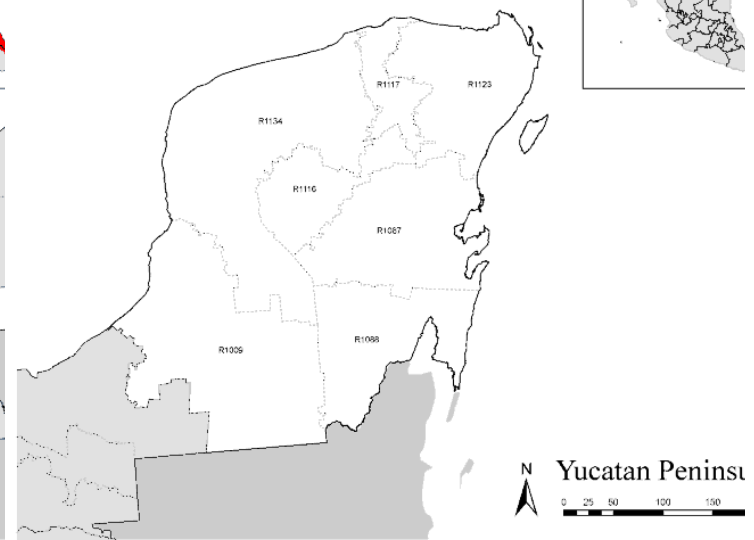

Source: Own elaboration based on Bassols-Batalla (1993,

2002) (Digital Cartography from the Municipal Geo-statistical Framework and the Topographic Digital Dataset) 
Figure A.11 Regionalisation: USA, Far West

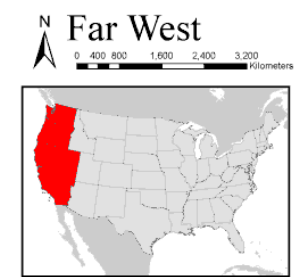

Source: Own elaboration based on the Bureau of Economic Analysis (2004a) (Digital Cartography the National Transportation Atlas Database, BTS)

Figure A.13 Regionalisation: USA, Southeast

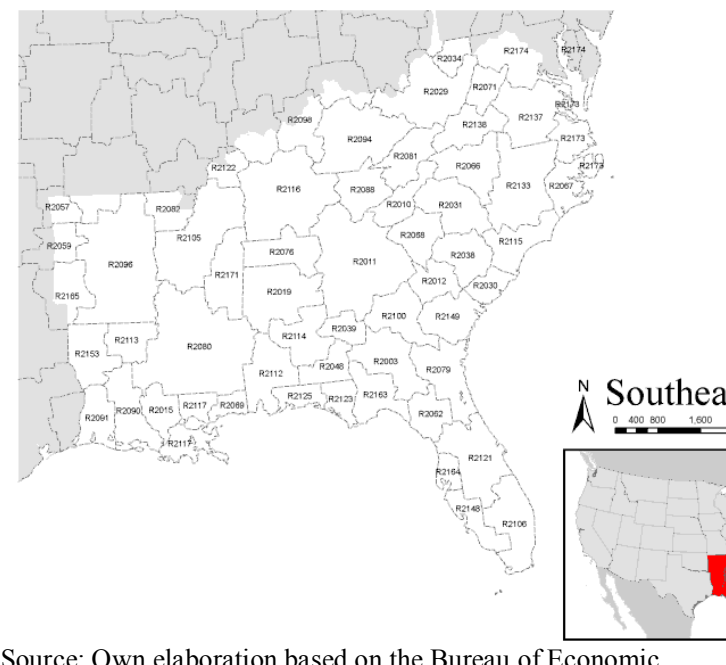

Source: Own elaboration based on the Bureau of Economic Analysis (2004a) (Digital Cartography the National Transportation Atlas Database, BTS)
Figure A.12 Regionalisation: USA, Southwest

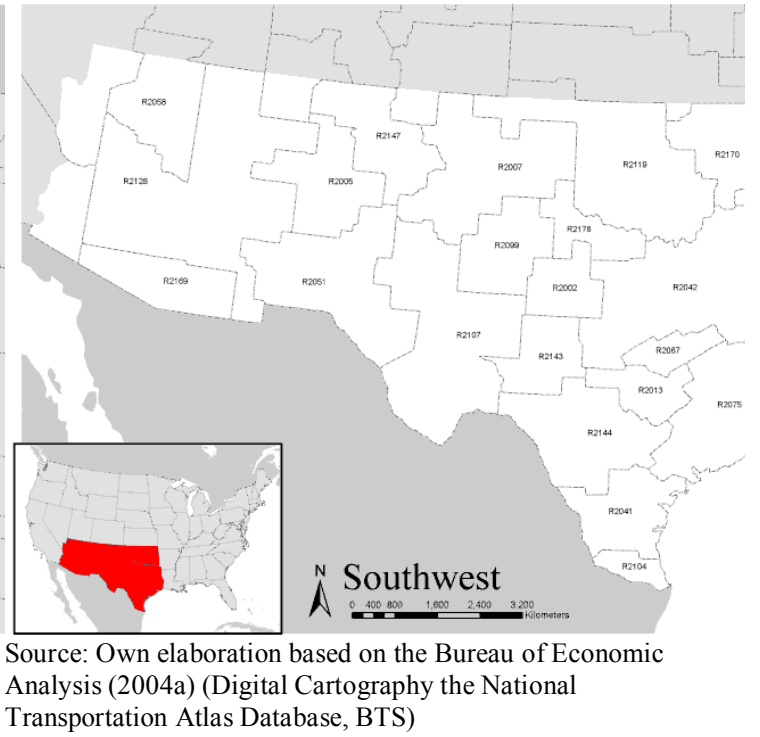

Figure A.14 Regionalisation: USA, New

England

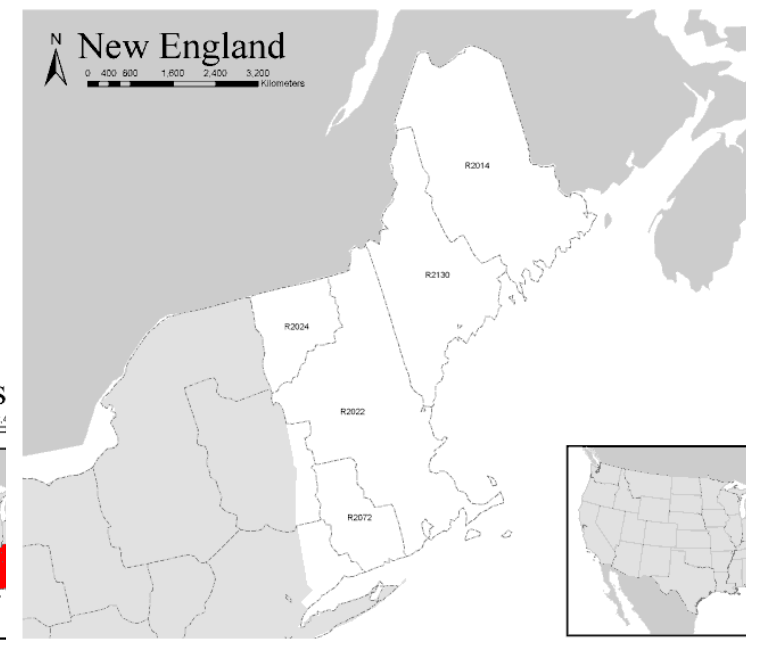

Source: Own elaboration based on the Bureau of Economic Analysis (2004a) (Digital Cartography the National Transportation Atlas Database, BTS) 
Figure A.15 Regionalisation: USA, Mideast

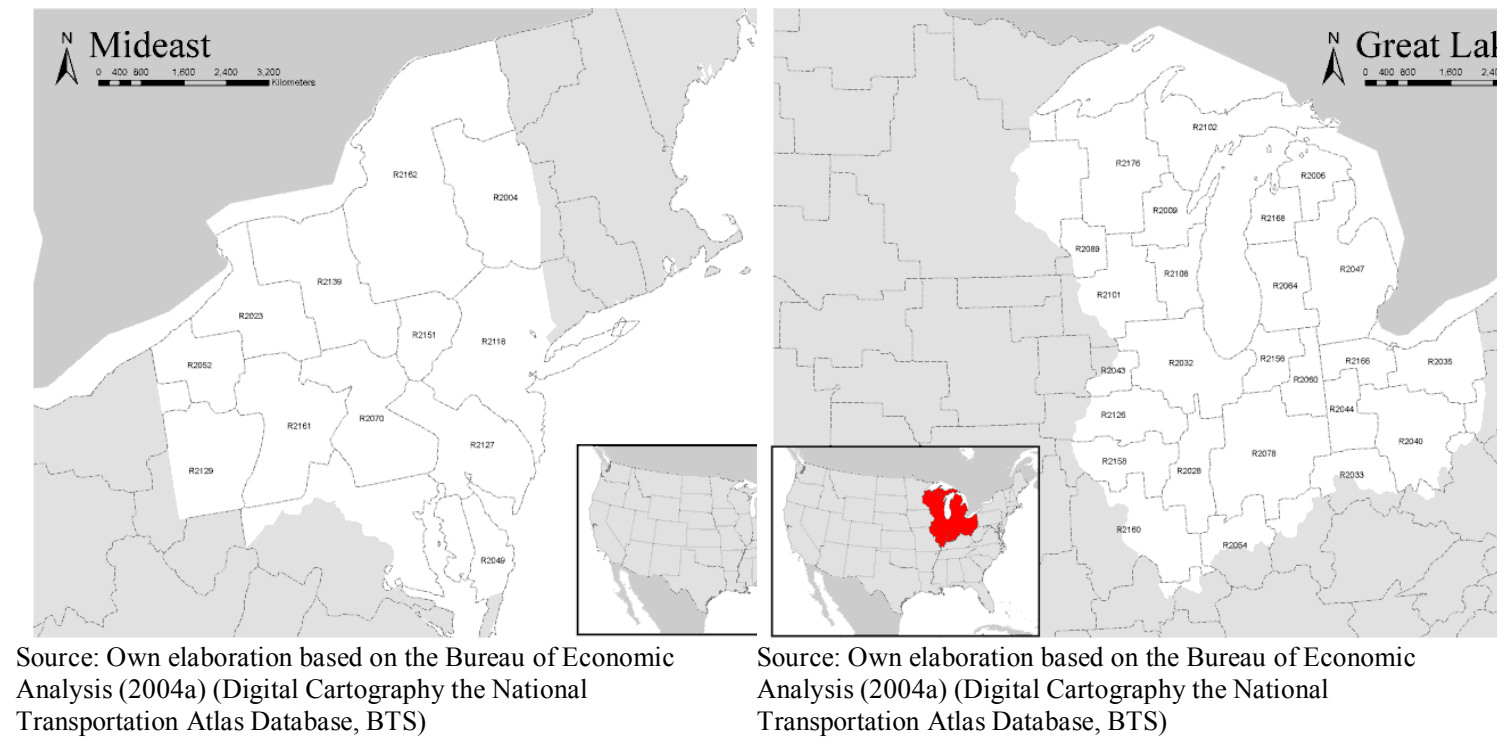

Figure A.17 Regionalisation: USA, Plains

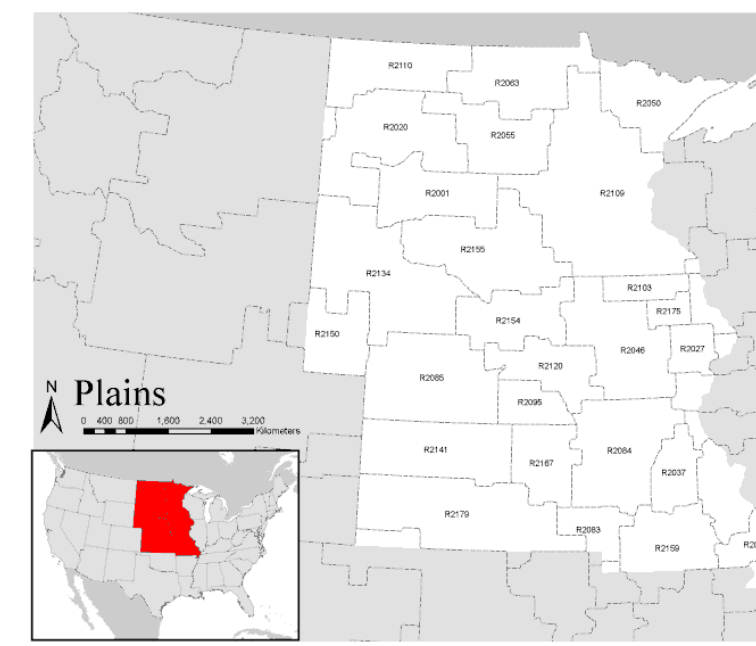

Source: Own elaboration based on the Bureau of Economic Analysis (2004a) (Digital Cartography the National Transportation Atlas Database, BTS)
Figure A.16 Regionalisation: USA, Great

Lakes

Figure A.18 Regionalisation: USA, Roky

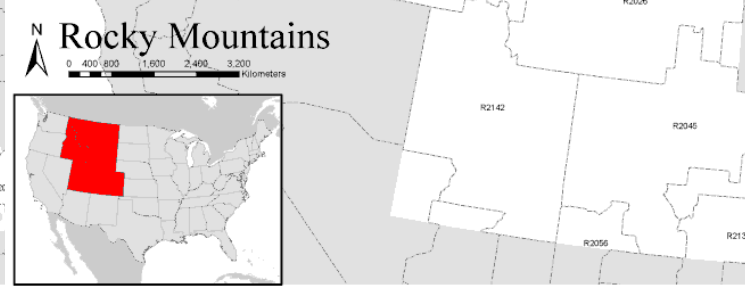

Source: Own elaboration based on the Bureau of Economic Analysis (2004a) (Digital Cartography the National Transportation Atlas Database, BTS) Mountains 